\title{
REVIEW
}

\section{Oligotrophy and pelagic marine bacteria: facts and fiction}

\author{
Frits Schut ${ }^{1}$, Rudolf A. Prins ${ }^{2, *}$, Jan C. Gottschal ${ }^{2, * *}$ \\ ${ }^{1}$ Microscreen b.v., Zernikepark 8, 9747 AN Groningen, The Netherlands \\ ${ }^{2}$ Department of Microbiology, University of Groningen, Kerklaan 30, 9751 NN Haren, The Netherlands
}

\begin{abstract}
Oligotrophy, or the inability of bacterial cells to propagate at elevated nutrient concentrations, is a controversial phenomenon in microbiology. The exact cause of the unculturability of many indigenous marine bacteria on standard laboratory media has still not been resolved. Unfortunately, the physiology of such cells is difficult to investigate as long as high cell density cultures cannot be obtained. An extensive evaluation of experiments relating to oligotrophy and the cultivation of marine bacteria is presented in this review. When incorporating the findings of studies performed with molecular biological methods, the picture emerges that indigenous marine bacteria can be cultivated under certain conditions and that the 'oligotrophic way of life' is a transient characteristic. Although strong generalisations should not be made with respect to a biological system as diverse as the world's oceans, it should be anticipated that cells with unique physiological characteristics appear to exist in the oceanic system. When combining conventional physiological approaches with molecular biological techniques it is feasible to unveil the phenotypes that go with the encountered genotypes. In view of the enormous complexity of the oceanic system this will prove an ambitious, yet resourceful undertaking
\end{abstract}

KEY WORDS: Oligotrophy Unculturable bacteria - Uptake kinetics · Marine bactería . Isolation procedures

\section{BACTERIA IN THE MARINE FOOD WEB}

\subsection{Introduction}

Heterotrophic bacteria constitute the major biomass component of oligotrophic marine ecosystems. As reservoirs of nutrients, they interact with all trophic levels and they control the nutrient fluxes in the system via mineralisation. Many free-living marine bacteria

- Prof. Dr Rudolf Prins died on 26 February 1997, after a long illness, while this manuscript was in its final phase of preparation and had just been accepted for publication. For many years R. A. Prins had been a stimulating force behind the study of oligotrophic marine bacteria.

- Addressee for correspondence.

E-mail: j.c.gottschal@biol.rug.nl belong to the smallest of all living cells. It is sometimes believed that these so-called ultramicrobacteria resemble starvation-induced miniaturised forms of bacteria that normally live attached to organic detritus and are intrinsically larger. However, per unit of volume, ultramicrobacteria express higher metabolic activity than such large cells, thereby representing the ocean's main bacterial component in terms of both activity and biomass. Nevertheless, an estimated $99 \%$ of these cells have never been characterised physiologically. The reason for this is that ultramicrobacteria belong to the notorious group of 'non-culturable' bacteria: bacteria that cannot be isolated and cultivated on standard laboratory media or under conventional laboratory conditions outside their natural habitat. It therefore seems that in the ocean, conditions prevail which are not easily reproduced in the laboratory. Such con- 
ditions, their effect on living organisms and the adaptations that they have induced are of considerable scientific interest. Historically, 2 rather separate lines of research have developed that, depending on the working hypotheses for the natural state of marine bacteria, either focus on the starvation response of marine isolates under laboratory conditions or attempt to demonstrate the presence of large numbers of obligately oligotrophic bacteria. This review summarises 2 decades of microbiological research in this field in an attempt to separate facts from fiction.

\subsection{The environmental conditions}

The marine system represents $90 \%$ of the biosphere and brings about one-third of the world's primary production. Consequently, the ocean is often considered a marine desert. However, the biomass of the oceanic primary producers (phytoplankton) represents a very small fraction $(0.05 \%)$ of their terrestrial functional equivalents (Begon et al. 1986). Therefore, per unit of biomass, oceanic ecosystems are far more productive than terrestrial ecosystems and the turnover rate of nutrients per unit of biomass is, as a result, several hundreds of times higher. Due to limited nutrient availability and low population densities, the effective overall turnover rate is still so low (Münster 1993) that the ocean classifies as oligotrophic with organic carbon fluxes of only a fraction of a milligram of carbon $\mathrm{l}^{-1} \mathrm{~d}^{-1}$ (Poindexter 1981). It is important to understand that such oligotrophic environments are characterised by a low nutrient flux as well as by low ambient concentrations of nutrients.

The marine pelagic ecosystem generally lacks exogenous nutrient inputs. Therefore, marine bacteria, which are believed to be limited in their growth by carbon (Kirchman 1990), ultimately rely on the release of photoassimilated carbon compounds by phytoplankton cells (McManus \& Peterson 1988, Kirchman et al. 1989. Billen et al. 1990). Taking into account that marine bacteria dominate the overall biomass of marine ecosystems (Fuhrman et al. 1989), thereby retaining most of the available nutrients and controlling the rate and the extent of primary production, it is evident that a close mutual dependence exists between bacteria and phytoplankton (Fuhrman \& Azam 1982, Larsson \& Hagström 1982, Linley et al. 1983, Cho \& Azam 1988, Hagström et al. 1988, McManus \& Peterson 1988, Billen et al. 1990).

The nanomolar concentrations of the available carbonaceous compounds are often considered too low to allow for growth of the bacteria (Poindexter 1981, Morita 1988). These low concentrations are in part the result of the uptake activities of the bacteria them- selves. It was shown long ago that bacterial growth in the euphotic zone can take place at the relatively high rates of $0.05 \mathrm{~h}^{-1}$ (Sieburth et al. 1977, Carlucci \& Williams 1978, Karl 1979).

\subsection{Characteristics of indigenous bacteria}

After viruses, heterotrophic bacteria are the most abundant members of the microbial community in the oligotrophic ocean (Dortch \& Packard 1989, Fuhrman et al. 1989). Their average cell volume is on the order of 0.02 to $0.12 \mu^{3}$ (Bjørnsen 1986, Lee \& Fuhrman 1987, Børsheim et al. 1990, Nagata \& Watanabe 1990), compared to 0.34 to $6.0 \mu^{3}$ for heterotrophic bacteria usually isolated from seawater (Mårdén et al. 1985 , Nyström et al. 1986, Nissen 1987, Moyer \& Morita 1989). Furthermore, with approximately 1 to $2.5 \mathrm{fg}$ of DNA cell-1 (Fuhrman \& Azam 1982, Schut et al. 1993) their genome size is less than $50 \%$ of a single copy of the genome of Escherichia coli (Ingraham et al. 1983). Natural communities of bacteria are very rich in carbon and nitrogen. They contain 23 to $38 \%(\mathrm{w} / \mathrm{v})$ carbon (Bjørnsen 1986, Lee \& Fuhrman 1987). In laboratory cultures of $E$. coli this value is $12 \%$ (Ingraham et al. 1983). The relative protein content of naturally occurring bacteria is inversely related to their cell volume (Simon \& Azam 1989), and their high nitrogen content is reflected in low C:N ratios of 3 to 5 (Goldman et al. 1987, Lee \& Fuhrman 1987). In all, indigenous marine bacteria appear to be quite different from the cells normally cultivated in laboratories around the world. But there is no certainty as to whether they represent unknown species with novel characteristics since more than $90 \%$ of the bacterial cells in oceanic waters have never been cultured or characterised.

\subsection{Aggregates: the nutritional escape?}

Besides release of photosynthate by living phytoplankton, plankton mortality and subsequent release of cellular remnants is an important source of organic carbon in the oceans. All organisms eventually end up in a detritus pool. Upon aggregation, such particles can rapidly sink out of the euphotic zone (Riley 1963). Large flocculant aggregates often contain detritus bound together within a gelatinous matrix (Wiebe \& Pomeroy 1972, Alldredge \& Silver 1988) and they appear in eutrophic as well as in oligotrophic areas. Some are visible to the naked eye and have been named 'marine snow' (Suzuki \& Kato 1953). Their chemical composition is heterogeneous with significant amounts of carbohydrates, protein and mucus 
(Wiebe \& Pomeroy 1972). As a microhabitat, aggregates form a much improved nutrient environment with concentrations of nitrogen and carbon several orders of magnitude higher than those in the surrounding water (Alldredge \& Silver 1988). Carbon:nitrogen ratios are still relatively low ( 7 to 10 ) (Alldredge 1979), suggesting high potential regeneration rates of ammonium. High primary production rates, as a result of this, have indeed been found in aggregates (Gotschalk \& Alldredge 1989). Moreover, because of their low surface charge, aggregates can collect DOC of low and high molecular weight, and may serve directly and indirectly as a food supply for bacteria (Wangersky 1977, Kjelleberg et al. 1982, 1983, 1985, 1987, Kjelleberg 1984)

The bacteria present in aggregates are typically much larger than the free-living bacteria (Ferguson \& Rublee 1976, Eguchi \& Kawai 1992) and acquire relatively high intrinsic growth rates upon the addition of exogenous substrates (Wiebe \& Pomeroy 1972). Furthermore, the viable count, or the number of colonies that appear when agar media are inoculated with seawater samples, is strongly correlated to the number of attached bacteria (Fukami et al. 1983), suggesting that attached bacteria represent the normal plate-isolates. Recently, DeLong et al. (1993), using 16S rRNA sequence data to investigate the phylogenetic diversity of free-living and aggregate-attached bacteria, showed that the free-living cells belonged mostly to the SAR11 cluster of marine bacteria ( $\alpha$-subclass Proteobacteria; see section 5.3), whereas the attached cells were mostly related to cytophaga-flavobacteria or $\gamma$-subclass of Proteobacteria in this study.

The contribution of these particle-bound bacteria (epibacteria) to the utilisation of DOC compounds is a matter of controversy. Both high (Hodson et al. 1981, Kirchman \& Mitchell 1982, Jeffrey \& Paul 1986) and low (Azam \& Hodson 1977. Nagata 1987, Simon 1987. Iriberri et al. 1990) incorporation rates in epibacteria relative to the free-living population have been reported. It seems justifiable to conclude that epibacteria do not grow faster than free-living cells (Fletcher 1984, Hoppe 1984, Iriberri et al. 1990). When considering that the biomass of epibacteria relative to that of free-living cells is very low in the open ocean (Ferguson \& Rublee 1976, Azam \& Hodson 1977, Iriberri et al. 1990), their overall contribution to bacterial production and turnover of DOC becomes insignificant, i.e. $<10 \%$ in pelagic regions (Williams 1970, Azam \& Hodson 1977, Fuhrman \& Azam 1980, 1982, Cho \& Azam 1988).

There are at least 2 different major views on the ecological role of attached bacteria (Kjelleberg et al. 1987 . Cho \& Azam 1988). One hypothesis (Kjelleberg et al. 1987) considers that aggregates are a refuelling station for marine bacteria that are in a constant transient state between growth and non-growth. Attached cells contribute to most of the productivity measured in seawater, while detached cells rapidly adapt to the low nutrient conditions and can contribute significantly to the community activity even though they do not grow. These cells return to the aggregate in order to grow. The other hypothesis considers attached bacteria responsible for rapid solubilisation of the detrital particles via exohydrolase activity (Hollibaugh \& Azam 1983. Cho \& Azam 1988, Smith et al. 1992) thereby releasing DOC as well as their own progeny as freeliving cells. The low molecular weight compounds are subsequently utilised by the free-living microbial community. In this hypothesis, epibacteria, although relatively unimportant in direct bacterial secondary production, play a major role in the pelagic ecosystem by supplying the free-living bacteria with readily utilisable substrates (Azam \& Cho 1987).

In the present study, we focus on the free-living, or pelagic, marine bacteria that are the representatives of the truly low-nutrient-adapted indigenous bacteria. Their characteristics are solely known from direct studies on the entire bacterial population in seawater samples, and from microscopic observations. Still, if properly analysed, these results might give us some information on how these cells are able to grow or survive in their environment, where they come from, and what methods should be employed to further investigate them.

\subsection{Substrate utilisation and mineralisation}

Carbon-limited bacteria should make efficient use of all carbonaceous compounds available to them. The relatively low bacterial standing stock (approx. 2 to $\left.25 \mu \mathrm{g} \mathrm{C}^{-1}\right)$ as compared to the DOC levels in the sea ( 0.1 to $1 \mathrm{mg} \mathrm{C}^{-1}$ ) indicates, however, that only a fraction of the organic matter is utilised by the bacteria. This may be indicative of the refractory nature of this material (Riley 1963, Menzel 1964, Jannasch 1967, Bada \& Lee 1977, Dawson \& Gocke 1978, Ammerman et al. 1984), as was reviewed by Münster (1993). The benefit of recalcitrant plant structures to terrestrial flora is well known and most of the data on refractory humic compounds in DOC pools come from soil and fresh water studies (Münster 1985, 1993). However, the accumulation of such compounds by marine phytoplankton would, in view of its dependence on high mineralisation rates, be ultimately adverse. It is therefore more likely that autochthonous high molecular weight compounds are completely degraded. As Wangersky (1977) put it boldly: 'If there really were organic compounds in the ocean, perhaps as complex 
polysaccharides, which could not be broken down by marine bacteria, we would be hip-deep in maple syrup by now. If such compounds also contained even the smallest amount of nitrogen or phosphorus, the maple syrup would also be sterile.' Whereby he probably meant that life itself would no longer exist.

Due to the nature of the substrate uptake systems, most substrates utilised by marine bacteria presumably consist of small molecules such as sugars, amino acids and small oligopeptides (Azam \& Fuhrman 1984). Most amino acids are indeed utilised by natural assemblages of marine bacteria (Hagström et al. 1984) and most individual cells capable of nutrient uptake exhibit in situ uptake of dissolved free amino acids (DFAA) (Jørgensen \& Søndergaard 1984, Tabor \& Neihof 1984 , Fuhrman \& Ferguson 1986, Coffin 1989). Ninety percent of the nitrogen requirements of bacteria in oligotrophic regions is believed to be covered by free ammonium and DFAAs (Keil \& Kirchman 1991), suggesting that dissolved combined amino acids (DCAA) play a relatively minor role as a direct source of nitrogen (Keil \& Kirchman 1991). DCAAs and polymeric carbohydrates may act as a source of free monomers. Exoproteolytic (Sommville \& Billen 1983) and exosaccharolytic (Hoppe 1983, Sommville 1984) activity is present in oceanic samples, and some marine bacteria possess cell surface and periplasmic aminopeptidases (Hollibaugh \& Azam 1983. Sommville \& Billen 1983, Vives Rego et al. 1985, Azam \& Cho 1987, Martinez \& Azam 1993). Polymeric carbohydrates can actually be utilised at high rates by natural assemblages of marine bacteria grown in chemostats (Hagström et al. 1984). Evidently, there must be bacteria that are very capable of degrading high molecular weight substances. It is presently unclear which bacteria are responsible for these activities, but in conjunction with the postulated solubilising activity of (attached) epibacteria (Hollibaugh \& Azam 1983, Azam \& Cho 1987. Cho \& Azam 1988. Smith et al. 1992) it is most likely that these cells play a crucial role in the initial breakdown process, and less so in the scavenging of dilute monomers.

By fractionating DOC pools, it was recently demonstrated (Amon \& Benner 1994) that high molecular weight $\mathrm{DOC}$ compounds $\left(\mathrm{M}_{\mathrm{r}}>1000\right.$; high $\mathrm{C} / \mathrm{N}$ ratios, primarily carbohydrates) are utilised more completely and more rapidly than low molecular weight compounds (low $\mathrm{C} / \mathrm{N}$ ratios, primarily amino acids) in seawater incubations. The outcome of such studies should, however intriguing, be carefully interpreted. Uptake studies with incubated seawater samples, especially when amended with inorganic nitrogen and phosphate and incubated for long periods ( 1 wk), as in this experiment, are prone to significant error due to the outgrowth and eventual dominance of an insignificant subpopulation of the original community.

\section{EVIDENCE FOR OLIGOTROPHIC BACTERIA: THE PUZZLE}

\subsection{Copiotrophs versus oligotrophs}

The dimension and permanent character of the phenomenon of growth limitation in nature has resulted in special life strategies. Two such strategies are recognised by ecologists (Andrews \& Harris 1986). Evidence for their existence in micro-organisms was obtained via competition studies in chemostats (Veldkamp et al. 1984, Jannasch \& Egli 1993). At low substrate concentrations, $r$ (growth rate)-selected organisms that grow rapidly at low population densities are outcompeted by $\mathrm{K}$ (carrying capacity)-selected organisms that are well adapted to nutrient dcpletion. r-strategists have short bursting growth phases and a tendency to produce resting-stage cells, whereas the K-strategists grow slowly but have the ability to capture low levels of nutrients (Andrews \& Harris 1986).

Classically, soil microflora is devided into 'zymogenous' and 'autochthonous' bacteria (Winogradsky 1949). The allochthonous zymogenous bacteria effectuate a rapid but incomplete degradation of organic material, thereby dispersing low concentrations of metabolic products (see also Kuznetsov et al. 1979). The larger population of slowly growing autochthonous, or indigenous, bacteria brings about the degradation of dispersed residual and more stable compounds. In aquatic microbiology, Winogradsky's division was adopted with slight modifications in terminology over the years. Zymogenous bacteria are currently called 'copiotrophs' (Poindexter 1981, Fry 1990), which is analogous to 'saprophytes' (Kuznetsov et al. 1979), 'eutrophs' (Yanagita et al. 1978, Martin \& MacLeod 1984, Ishida et al. 1986) and 'heterotrophs' (Akagi et al. 1980). Autochthonous bacteria are called 'oligotrophs' (Poindexter 1981, Fry 1990), although 'oligocarbophiles' (Moaledj 1978), 'low-nutrient (LN) bacteria' (Carlucci \& Shimp 1974), 'low $K_{\mathrm{s}}$ bacteria' (Baxter \& Sieburth 1984) or 'DNB (dilute nutrient broth) organisms' (Kasahara \& Hattori 1991) may also be encountered in the literature. The use of the various terms for the 2 groups is mainly determined by whether the authors belong to the Russian, German Anglo-American or Japanese 'school'

There is a confusing variety of definitions for oligotrophic bacteria (see Table 1). Some researchers define oligotrophs as organisms able to grow at nutri-

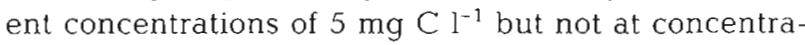
tions of $7.5 \mathrm{~g} \mathrm{C} \mathrm{l}^{-1}$ (Yanagita et al. 1978). Others define oligotrophs as those bacteria that are able to grow on media with 1 to $15 \mathrm{mg} \mathrm{C}^{-1}$ as well as on media with a higher nutrient content (Kuznetsov et al. 1979). Ishida et al. (1986) call such organisms facultative oligotrophs 
Table 1. Defintions used to characterise oligotrophic bacterla

\section{Definition}

'Oligotrophic bacteria are heterotrophic bacteria capable of growth in the presence of organic nutrients equivalent to $16.8 \mathrm{mg} \mathrm{Cl}^{-1}$

'Bacteria capable of growth on unamended BWA (agar-solidified Chesapeake Bay water)'

'Olıgocarbophilic bacterla are capable to grow on media contaning only minerals, and they meet their carbon and energy requirements from trace amounts of organic substances $|\ldots|$ found in the air.'

'A trophic group of bacteria that can grow only in the presence of a minor amount of nutrilites and not in the presence of a large amount.'

'Those [bacteria] that develop at the first cultivation on media with the minimal content of organic matter of about $1-15 \mathrm{mg} \mathrm{C} / \mathrm{l}$ and that grow on such media at subsequent recultivation though they can grow on richer media.'

'Organisms that grow in media containing organic matter at a concentration of $1 \mathrm{mg}$ $C$ per litre. [...]. Obligate oligotrophs may decrease in number or disappear with the onset of man-made eutrophication, facultative oligotrophs can tolerate or rapidly adapt to the higher concentrations of organic substances.

'Oligotrophic bacteria can [...] be conceived of as those whose survival in nature depends on their ability to multiply in habitats of low nutrient fluxes (approaching zero to a fraction of a mg C/litre/day).'

'Bacteria which grow at substrate concentrations of less than $1 \mathrm{mg}$ carbon $\mathrm{l}^{-1}$.'

'Bacteria that can be isolated on a low-nutrient medium (unsupplemented

Bushnell Haas agar) and that are restricted to growth at low nutrient concentrations.'

'Oligotrophs are defined as those organisms known to be able not only to survive but particularly to multiply under conditions of extremely low and often discontinuous supply of nutrients. In other words, organisms adapted to low and irregular fluxes of substrates.'

'Obligately oligotrophic bacteria are capable of growth in $\mathrm{SF} 10^{-4}\left(0.2 \mathrm{mg} \mathrm{Cl}^{-1}\right)$ but not in $\mathrm{SF} 10^{-1}\left(200 \mathrm{mg} \mathrm{Cl}^{-1}\right)^{\prime}$

'Among oligotrophs we tentatively define the obligate oligotroph as an organism which does not grow in rich ( $200 \mathrm{mg} \mathrm{C/l}$ ) media, and the facultative oligotroph as an organism which grows in not only poor $(0.2 \mathrm{mg} \mathrm{C} / \mathrm{l})$ but also rich media.'

'Oligotrophic isolates are defined as bacteria capable of growth on OEMS agar $\left(0.4 \mathrm{mg} \mathrm{C}^{-1}\right)$.'

'Oligotrophic bacteria can broadly be defined as organisms that grow on low concentrations of organic substrates' Obligate oligotrophs cannot grow at substrate concentrations above $6 \mathrm{~g} \mathrm{C} \mathrm{l}^{-1}$

'... oligotrophic micro-organisms are prokaryotic and eukaryotic organisms that are evolutionarily adapted to exploit ecological niches characterised by low substrate concentrations and low energy fluxes. Oligotrophs, $[\ldots]$ may develop in rich as well as in poor environments [.... .'
Source

Akagi et al. (1977)

Mallory et al. (1977)

Moaledj (1978)

Yanagita et al. (1978)

Kuznetsov et al. (1979)

Ishida \& Kadota (1981)

Poindexter (1981)

Ishida et al. (1982)

Horowitz et al. (1983)

Van Gemerden \& Kuenen (1984)

Ishida et al. (1986)

Ishida et al. (1989)

Upton \& Nedwell (1989)

Fry [1990]

Semenov (1991) (see also Yanagita et al. 1978), as opposed to obligate oligotrophs that cannot grow at substrate concentrations above $0.3 \mathrm{~g} \mathrm{C} \mathrm{l}^{-1}$. Horowitz et al. (1983) postulated the term euryheterotroph for facultative oligotrophic bacteria and Baxter \& Sieburth (1984) replaced 'facultative oligotroph' by 'eurytroph'. The confusion on the proper definition is strengthened by the fact that some researchers use the term oligotroph only for those organisms that are restricted to growth on low nutrient media, while others employ the term to broadly speak about both the obligate and facultative oligotrophs. Whether there is a single characteristic for 'oligotrophic bacteria' thus strongly depends on its definition. A general characteristic of oligotrophs, and one that is currently used in all definitions, is the ability to grow in low nutrient media $\left(0.2\right.$ to $\left.16.8 \mathrm{mg} \mathrm{Cl}^{-1}\right)$. But is this truly such a remarkable characteristic?

In the ocean's euphotic zone, food often comes in waves (Mopper \& Lindroth 1982, Harvey 1983) and the availability is short lasting. In river-outflow regions, or during senescence of massive phytoplankton spring blooms, conditions may actually be eutrophic. By definition such regions are characterised by a more than 50 -fold higher nutrient flux than that in oligotrophic 
regions (Poindexter 1981). Yet, rapid growth of bacteria and consumption of substrates will again result in low steady state substrate concentrations and growth limitation. Therefore, eutrophic environments select temporarily for $K$-strategists when nutrients become depleted (Andrews \& Harris 1986). The fluctuations in nutrient availability in the ocean and the presence of microniches result in the coexistence of copiotrophic and oligotrophic bacteria in an oligotrophic environment. Therefore, the r/K-selection concept is not completely synonymous with the copiotrophic/oligotrophic concept (Andrews \& Harris 1986), and this is probably the reason why the $\mathrm{r} / \mathrm{K}$-strategy concept has not been broadly adopted in marine microbiology. The reason why a broad division of bacterial phenotypes is nevertheless so deeply rooted in marine microbiology largely stems from the unculturability of the bacteria present and the presurned sensitivity of these bacteria to high carbon concentrations. But whether the ocean indeed contains large numbers of obligately oligotrophic bacteria has never been conclusively demonstrated.

\subsection{Unculturability on agar media}

As the exact substrate requirements of heterotrophic marine bacteria are not known, media for their isolation are usually composed of complex mixtures of organic substrates. Some of the most commonly applied isolation media are listed in Table 2. Heterotrophic plate counts generally indicate that less than $0.1 \%$ of the population observed by direct microscopy can grow on these media (ZoBell 1941, Jannasch \& Jones 1959, Kogure et al. 1980, Van Es \& Meyer-Reil 1982, Poindexter \& Leadbetter 1986, Roszak \& Colwell 1987, Austin 1988).

The reason why only low numbers of colonies develop on agar plates after inoculation with marine or other environmental samples can be attributed to several factors. A few of these deserve special attention. (1) The first reason may be the inactivation of cells by other cells in their immediate vicinity, resulting in only a few colonies sufficiently separated from each other. This possibility was clearly demonstrated by Pratt \& Reynolds (1974). (2) Another reason may be that some bacteria may not be able to grow on the substrate or the combination of substrates provided. Much work has been done to optimise growth media (ZoBell 1941, Buck 1974, 1979, Simidu 1974), mostly without significant improvements in culturability. Particular substrate imbalances of the medium relative to cellular requirements together with limited metabolic regulatory abilities of the cells may impede growth. (3) The induction of the lytic cycle of temperate phages upon improve- ment of the nutritional status of the cell could aiso serve as an explanation. In one study (Heldal \& Bratbak 1991), up to $14 \%$ of the bacteria in seawater contained mature virus particles! If these numbers represent infection rates with virulent bacteriophage, the number of bacteria that is infected with temperate (lysogenic) bacteriophage may be even higher, since the latter type is more common (Heldal \& Bratbak 1991). This subject is still largely unexplored, though of obvious importance. Button and co-workers (Button et al. 1993, Schut et al. 1993) observed the deleterious effect of viruses on the development of bacterial cultures in dilution cultures from natural seawater (see below). Rehnstam et al. (1993) also suggested that phage infection can lead to differences in culturability in genetically homogeneous populations in seawater (see below). (4) Substrate may be suitable, but present at too high a concentration (Jannasch \& Jones 1959). This argument in general provides the basis for studying the phenomenon of obligate oligotrophy. The presumed existence of obligate oligotrophs is a most fascinating controversy in marine microbiology (Martin \& MacLeod 1984, Ishida et al. 1989, Eguchi \& Ishida 1990).

\subsection{Oligotrophic isolates: a contradiction in terms}

According to the definition for oligotrophic bacteria by Kuznetsov et al. (1979), the organic carbon content of only 2 media in Table 2 (LN and BM/SAS) is sufficiently low to allow growth of such cells, i.e. containing less than $15 \mathrm{mg} \mathrm{C}^{-1}$ in the form of amended substrates. In the remainder, the total amount of carbonaceous compounds is at least 1000 -fold higher than that in natural seawater. Although 'oligotrophic' substrate concentrations in the isolation medium can result in higher heterotrophic plate counts, the improvement in culturability is only marginal (Ishida et al. 1989). Possibly, the substrate concentrations are still too high to permit sustained growth.

Many so-called oligotrophs have been isolated on agar with low ( $\mathrm{mg}$ ) additions of organic carbon, or onagar-solidified unamended water samples. The agar itself, however, contains several hundred mg of utilisable sugars and amino acids $1^{-1}$ (Akagi et al. 1977, Baxter \& Sieburth 1984, Schut et al. 1993). As demonstrated by Button et al. (1993), growth of marine bacteria in a liquid medium consisting solely of filtered autoclaved seawater was completely prevented by the addition of $5 \mathrm{mg} \mathrm{Cl}^{-1}$. Other investigations have also reported that more that $99 \%$ of the indigenous seawater population did not grow in the presence of milligram quantities of added substrates (Akagi et al. 1977, Eguchi \& Kawai 1992). Milligram additions of 
organic carbon to seawater should thus not be made if dominant cells are to be obtained and the use of agar is for this reason undesirable. Moreover, the truly oligotrophic character of most isolates obtained on agar surfaces can thus be questioned. At first glance, natural seawater solidified with washed agar, as used in the BM/SAS medium of Carlucci et al. (1986), seems a proper isolation medium for naturally occurring marine bacteria. But in practice, such seawater-agar media did not significantly improve the culturability of the bacterioplankton. Altogether, the applicability of these plates should be questioned. Results from Li \& Dickie (1985) indicated that the maximum number of cells that developed in $20 \mathrm{ml}$ of unamended natural seawater was approximately $20 \times 10^{6}$. For cells of indigenous cell-volume, this is equivalent to approximately 10 microcolonies with a diameter of only $0.02 \mathrm{~mm}$ on an agar plate with solidified unamended seawater, provided that the cells extract every utilisable substrate molecule from that plate. This may serve to indicate that solid media are not suitable for the isolation of indigenous marine bacteria.

To bypass the problem of agar contamination, Akagi et al. (1977) developed a glass-fibre/Nuclepore filter technique to obtain colonies on a solid surface while nutrients were absorbed from dilute media $(16.8 \mathrm{mg} \mathrm{C}$ $\mathrm{I}^{-1}$, consisting primarily of peptone). The number of (oligotrophic) colonies thus obtained varied between $10^{1}$ and $10^{3} \mathrm{ml}^{-1}$ of seawater from oceanic regions and between $10^{2}$ to $10^{4} \mathrm{ml}^{-1}$ of seawater from coastal areas. Total bacterial counts were not given, but assuming the usually observed values of $10^{4}$ to $10^{6} \mathrm{ml}^{-1}$ and $10^{5}$ to $10^{7} \mathrm{ml}^{-1}$ for oceanic and coastal samples, respectively, the results indicate that the culturability increased only slightly by using this method. It must be noted that the glass-fibre/Nuclepore filters were transferred to agar in order to obtain visible colonies. The method therefore did not ensure oligotrophic conditions throughout the experiment and the result should be interpreted accordingly. Yanagita et al. (1978) used approximately the same filter method and found similar results. In any case, if oligotrophic bacteria exist as a dominant population in seawater, their growth will effectively be suppressed at $16.8 \mathrm{mg}$ peptone- $\mathrm{C}^{-1}$ using such procedures. Recently, Bianchi \& Guiliano (1996), using epifluorescence microscopy for the detection of ultramicrocolonies grown on the surface of $0.2 \mu \mathrm{m}$ polycarbonate membranes, found viability values often exceeding $20 \%$ in samples from the Mediterranean. An unexpected finding was that counts on membranes incubated on nutrient-rich media correlated better to the total direct counts than those obtained from nutrient-depleted incubations (2216 marine agar or $10 \times$ diluted Akagi LN medium-soaked cellulose pads, respectively; see Table 2). The highest number of viable cell counts was obtained when using unamended filtered seawater as MPN dilution medium.

Even synthetic seawater media that are prepared in the laboratory contain significant amounts of organic carbon compounds. These compounds will come from the dissolved salts or from the contaminated laboratory air. Furthermore, if trace metals and inorganic nutrients, such as phosphorus, are applied in amounts sufficient for the development of bacterial colonies on plates, organic chelators are required to prevent the complexation of these nutrients. Truly low-nutrient, synthetic seawater media are therefore difficult to prepare. In fact, natural seawater itself represents the ideal low-nutrient growth environment for marine bacteria.

\subsection{The search for the obligate oligotroph}

The documentation that exists on obligate oligotrophs isolated from natural systems is very limited and ambiguous. The most important reports will be addressed in some detail in order to properly evaluate the available results. Ishida \& Kadota (1981) reported the presence of obligate oligotrophs in Lake Biwa, Japan. This study is often referred to in communications on oligotrophy. However, the applied method contains a number of pitfalls not always recognised. The investigators used a ${ }^{14} \mathrm{C}-\mathrm{MPN}$ technique to demonstrate the increase in cell numbers in cultures grown at different trypticase/yeast extract (TY) concentrations $\left(0.55\right.$ to $5500 \mathrm{mg} \mathrm{l}^{-1}$ substrates; trypticase: yeast extract, 10:1). Growth was defined as the presence of ${ }^{14} \mathrm{C}$-labelled material in an MPN tube that could be retained on a $0.22 \mu \mathrm{m}$ Millipore filter (an MPN tube contained $0.5 \mathrm{mg} \mathrm{l}^{-1}$ trypticase plus $64 \mathrm{nM}{ }^{14} \mathrm{C}$ glutamate). After incubation, the highest TY concentration yielded fewer positive MPN tubes than lower TY concentrations and it was concluded that this was due to the presence of lower cell densities in the high nutrient cultures. As a result, the authors concluded that the organisms behaved as obligate oligotrophs.

A number of potential problems with this method should be considered. (1) Since not individual cells but ${ }^{14} \mathrm{C}$-containing particles were counted, the enumeration of cell populations was circumstantial and presents no direct evidence of whether cellular growth had occurred or not. (2) The possibility that growth cessation actually occurred during enumeration in MPN tubes and not in the TY tubes cannot be excluded. Cells from media with high TY concentrations were confronted with a double shift in nutrient availability whereas cells from low-nutrient media underwent no such shifts. (3) The maximum cell density of the cultures with $0.55 \mathrm{mg}$ of added substrates $\mathrm{I}^{-1}$ 


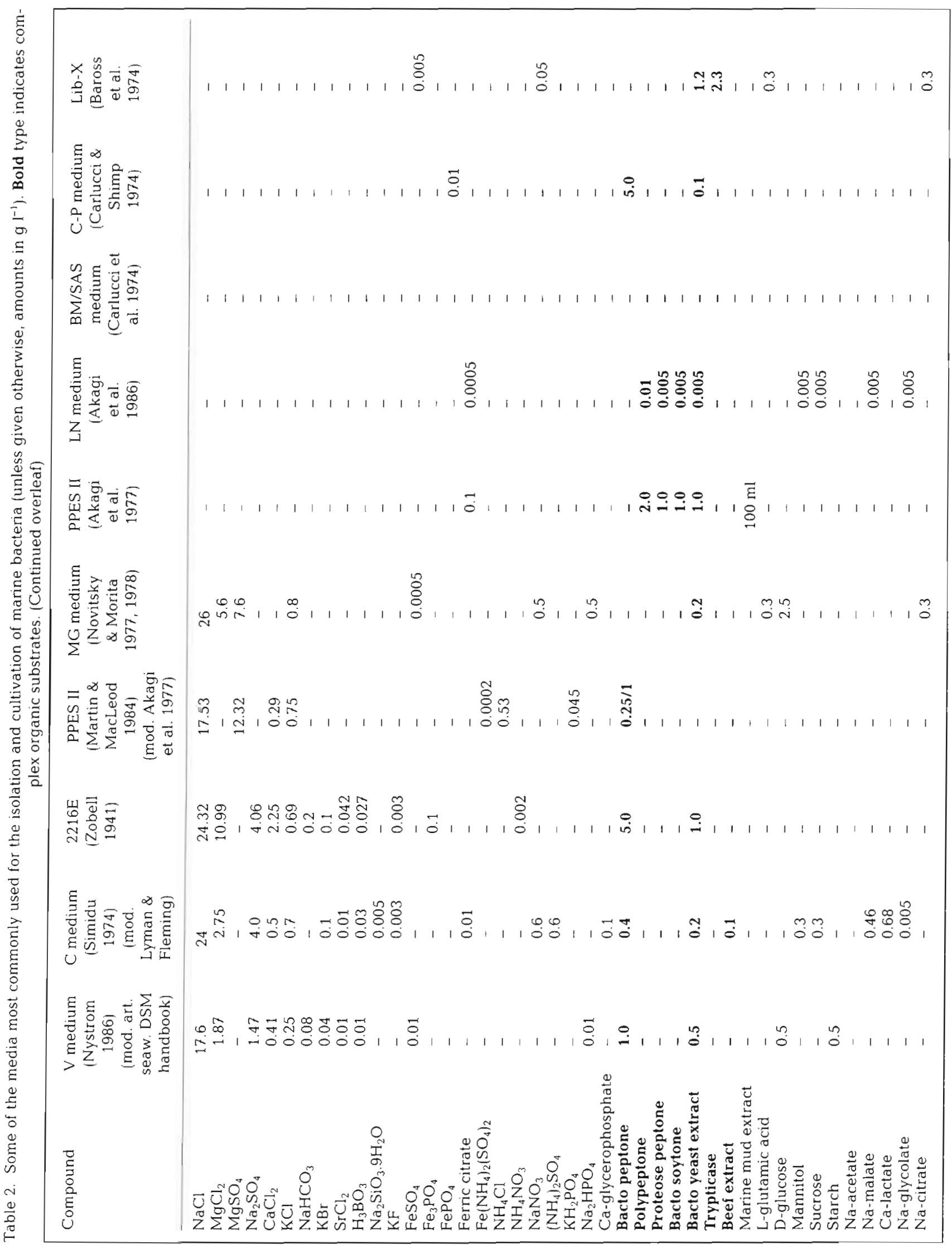




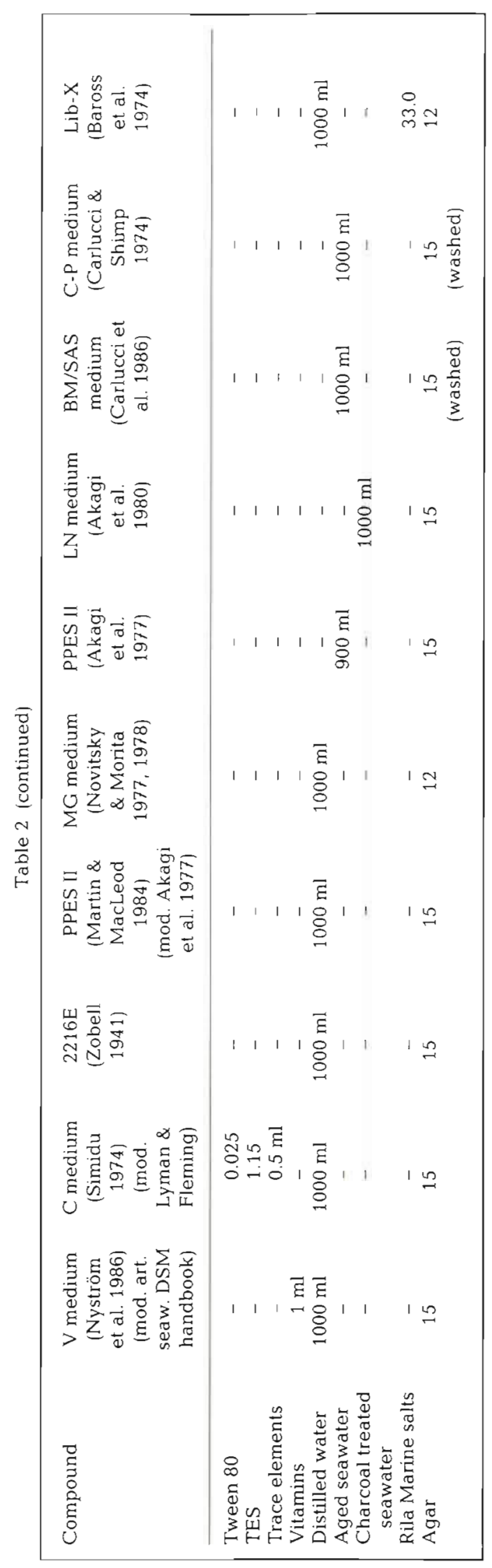

was only $2.5 \times 10^{5} \mathrm{ml}^{-1}$, which, together with the reported cell dimensions $\left(0.17 \times 0.75 \mu \mathrm{m}\right.$ or $\left.0.016 \mu \mathrm{m}^{3}\right)$ corresponds to approximately $1.4 \mathrm{~g} \mathrm{Cl}^{-1}$ and a carbon assimilation efficiency of only $0.25 \%$. This implies that apparently the medium provided no proper growth environment for these bacteria in the first place.

In later studies (Ishida et al. 1986, Eguchi \& Ishida 1990) a slight modification of the ${ }^{14} \mathrm{C}$-MPN method was used. In order to evaluate obligately oligotrophic growth from direct incubation of seawater samples, 2 different media were used $\left(\mathrm{ST} 10^{-4}\right.$ and ST10 ${ }^{-1}$ with $0.55 \mathrm{mg} \mathrm{l}^{-1}$ and $0.55 \mathrm{~g} \mathrm{l}^{-1}$ substrate, respectively) with TY at a ratio of 10:1. Growth in ST10 $10^{-1}$ was scored by turbidity, and growth in $\mathrm{ST}_{10} 0^{-4}$ was scored as ${ }^{14} \mathrm{C}$ accumulation after $4 \mathrm{wk}$. Such uptake abilities again do not necessarily reflect growth. In a more recent study, the ${ }^{14} \mathrm{C}$-MPN method was abandoned, and growth in ST10 ${ }^{-4}$ was scored by individual epifluorescence microscopic observations of the MPN tubes (Yoshinaga et al. 1991, Eguchi \& Kawai 1992). On average $80 \%$ of the obtained cultures from pelagic waters consisted of obligate oligotrophs, but the total number of obtained cultures resulted from growth of between 0.03 and $0.25 \%$ of the total number of cells present in the original sample. While the authors concluded that the predominant cells in the investigated pelagic waters were obligately oligotrophic, a more appropriate conclusion might have been that most cells were unable to grow under the given conditions. No published results on the cultures thus obtained are yet available (Yoshinaga et al. 1991).

\subsection{Lack of evidence for the existence of obligate oligotrophs}

Have any obligate oligotrophs been isolated at all? The isolation of obligate oligotrophs has been claimed by several authors (Yanagita et al. 1978, Ishida \& Kadota 1981, Fry 1990). Ishida \& Kadota (1981) obtained 18 obligate oligotrophs from lake water that could not grow on an agar surface. The 'strains' were obtained by successive dilution purification, and as such do not represent truly pure cultures. Fry (1990) described an obligately oligotrophic Pseudomonas sp. WOO1, which did not grow at total carbon concentrations above $6 \mathrm{~g} \mathrm{Cl}^{-1}$. This is not the kind of obligate oligotroph that is unable to grow on unsupplemented seawater agar media and Nuclepore filters soaked in low nutrient ( $\mathrm{mg} \mathrm{C} \mathrm{l}^{-1}$ ) media. Mallory et al. (1977) investigated the taxonomy of isolates from Chesapeake Bay that had low maximum growth rates on unsupplemented seawater agar (1.8\% agar). Although such cells were called oligotrophic they are beyond the scope of this discussion for the reasons mentioned 
above. For the same reason, the isolates obtained by Yanagita et al. (1978) as well as the marine Vibrio sp. of Baxter \& Sieburth (1984) that showed cell rupture at high glucose concentrations as the result of excessive intracellular polymer accumulation lack ecological significance in this respect. MacDonell \& Hood (1982) enriched filterable bacteria from an estuary in complex broth (Lib-X). Of the 27 enrichment cultures, 24 could initially not be grown on full-strength broths, including marine 2216 broth $\left(3 \mathrm{~g} \mathrm{C} \mathrm{l}^{-1}\right.$ ). After an adaptation period, consisting of repeated subcultivation of an enrichment culture on 'dilute' agar medium (BHES, $3.7 \mathrm{~g}$ brain heart infusion $\mathrm{l}^{-1}$ ), single colonies were obtained, indicating transformation from the obligate to the facultative oligotrophic phenotype. Nutrient conditioning was accompanied by an increase in cell size. No follow-up studies on these organisms have been reported.

Several Vibrio strains have been shown to produce cells with obligately oligotrophic properties after progressive low-nutrient conditioning (Hood \& MacDonell 1987). This was established by subculturing the strains in medium containing half the amount of carbon of the previous growth condition (from $3 \mathrm{~g} \mathrm{C}^{-1}$ down to approx. $1.5 \mathrm{mg} \mathrm{C}^{-1}$ ). The strains produced $0.4 \mu \mathrm{m}$ filterable cells. Around 80 to $90 \%$ of these filterable cells consisted of facultatively oligotrophic cells, whereas 10 to $20 \%$ of the cells exhibited distinctly obligately oligotrophic properties. Interestingly, Yanagita et al. (1978) have reported the isolation of an obligately oligotrophic Escherichia coli mutant obtained by UV irradiation. For obligate oligotrophy to be meaningful in relation to the unculturability of autochthonous bacteria, growth inhibition should be notable below the concentrations employed in the glass-fibre filter technique by Akagi et al. (1977) as discussed above. Growth inhibition at several grams of carbon $\mathrm{l}^{-1}$ is of no significance in relation to the natural situation.

From the above it should be concluded that (1) organisms with the nutrient sensitivity that is believed to exist in indigenous bacteria have never been obtained in pure culture, (2) no obligately oligotrophic species of bacteria are known to date, and (3) obligate oligotrophy has never been demonstrated to represent a 'stable' phenotype. The isolates and cultures that have been obtained either represent an infinitesimal fraction of the total planktonic population or can be cultivated on media on which planktonic bacteria refuse to grow. An interesting exception to this is formed by the isolates obtained of Rehnstam et al. (1993) that constituted a dominant part of the population as determined by $16 \mathrm{~S}$ rRNA probing. The majority of these cells could not form colonies on the agar medium employed when attempting their direct isolation from the seawater. This inability was explained by a low plating efficiency, possibly as a result of phage infection. Indeed, such cells may appear as 'obligate oligotrophs'

Nevertheless, obligate oligotrophy, as the impairment of growth at elevated substrate concentrations, does appear to exist as a state in which cells can occur. Hence, 'obligate oligotrophy' can, at present, best be understood as a transient characteristic only observed in cells that are taken directly from an extremely substrate-limited natural environment (MacDonell \& Hood 1982, Button et al. 1993, Schut et al. 1993) or that are gradually adapted to low-nutrient conditions (Hood \& MacDonell 1987). Whether the use of the term obligate is appropriate in this context is disputable. Statements about the 'obligately oligotrophic' nature of autochthonous malne bacierid or the characterisics of 'oligotrophic' bacteria in general are at this stage at least premature. Since sufficiently high cell densities are required for detailed physiological studies, truly 'obligately oligotrophic' marine bacteria cannot (yet) be adequately investigated.

\section{OLIGOTROPHS, COPIOTROPHS AND UNCULTURABILITY: THE CLUES}

\subsection{Adaptability: facultative oligotrophs}

Long before the low-nutrient isolation media came into fashion, it was established that bacteria currently termed 'copiotrophic' were able to grow in media with additions of glucose or peptone as low as $0.1 \mathrm{mg} \mathrm{l}^{-1}$ (ZoBell \& Grant 1943). The copiotrophs Pseudomonas aeruginosa and Aeromonas hydrophila can grow in tap water supplied with microgram quantities of organic carbon $1^{-1}$ (Van der Kooij et al. 1980, 1982), and should according to definitions be considered oligotrophic (Ohta \& Taniguchi 1988). All Enterobacteriaceae and most known pathogenic bacteria should be considered copiotrophic, yet 'oligotrophs' can be isolated from clinical samples (Tada et al. 1995). Also, copiotrophs form the majority of marine isolates. Based on their physiological response to nutrient limitation these organisms appear to be well adapted to growth under oligotrophic conditions (Gottschal 1990). As such they could in this respect be equally successful in the ocean as oligotrophic bacteria. Starvation regimes (Mårdén et al. 1987), continuous nutrient limitation (Collins et al. 1976, Höfle 1984) and growth at various substrate concentrations (Ishida et al. 1982) have been shown to alter the kinetics of substrate uptake significantly, thereby allowing organisms to capture nutrients more effectively at low concentrations.

Martin \& MacLeod (1984) have performed a series of experiments on oligotrophic and copiotrophic strains 
which very clearly illustrate the limitation of the definition of oligotrophic growth. The facultatively oligotrophic spp. O-81 and 486 were compared to the copiotrophic spp. RP-250 and RP-303. All 4 strains were previously isolated and characterised (Akagi et al. 1977, 1980). The results of the study by Martin \& MacLeod (1984) showed that the oligotrophs produced turbid cultures on $10 \mathrm{mg} \mathrm{l}^{-1}$ of peptone, whereas the copiotrophs did not. This confirmed earlier statements by Akagi et al. (1980) on the copiotrophic nature of strains RP-250 and RP-303. However, this distinction disappeared when peptone was replaced by amino acids or fatty acids as single carbon sources, indicating that the oligotrophic traits depended on the nature of the available substrates.

Employing low and high nutrient media, numerous facultatively oligotrophic bacteria (Moaledj 1978) and copiotrophic bacteria (Witzel et al. 1982) were isolated from the eutrophic Lake Plußsee, Germany, on the 2 plate types respectively. Among the oligotrophic isolates were several strains of Hyphomicrobium and Caulobacter, 2 well-known oligotrophic genera (Moaledj 1978, Poindexter 1981), as well as many Vibrio strains (Moaledj 1978). Cluster analysis was used to separate the 2 groups on the basis of various physiological, morphological and biochemical characteristics (Witzel et al. 1982). It was concluded from these and other studies that, in general, species isolated on lownutrient media differ from those isolated on highnutrient media (Jannasch 1967, Witzel et al. 1982 , Horowitz et al. 1983) and they generally exhibit lower maximum specific growth rates (Mallory et al. 1977). Furthermore, some species are better adapted to low nutrient conditions than others, as demonstrated by competition studies in chemostat (Veldkamp et al. 1984). Apart from that, there is insufficient evidence to permit a sharp division into oligotrophic species and copiotrophic species solely on the basis of growth abilities at various substrate concentrations. Oligotrophs can lose their ability to grow on low-nutrient media, thus becoming copiotrophs (Akagi et al. 1980). This, together with other findings on the ability of organisms to adapt to low and high nutrient concentrations, indicates that the 'trophic' characteristics of bacteria are by no means static parameters. A general division among bacteria on the basis of growth (in)abilities is therefore unfounded, particularly when differences between individual cells in pure cultures can exist (Hood \& MacDonell 1987).

Definitions may only have a right to exist when used in the context of the physiological state of the bacterium. Whether an organism is able to acquire a certain state may indeed depend on its general life-strategy. 'Obligate oligotrophy' upon first cultivation of bacteria from natural habitats is a well-documented phenomenon. An (obligately) oligotrophic cell could be (temporarily?) conditioned to high-nutrient situations and vice versa. Such conditioning can involve the expression of cryptic genes that code for so far unused proteins. Cryptic genes are reactivated by mutation, but can eventually be lost (Hall et al. 1984, Li 1984). In this context, the small genome size of pelagic bacteria (Fuhrman \& Azam 1982, Schut et al. 1993) may be the result of the loss of disused genomic material. Apart from the fact that this would also result in cells of small size (Stouthamer \& Kooijman 1993), it could result in the loss of metabolic traits, e.g. regulatory mechanisms. So, although a certain level of adaptability is a quality native to all bacteria, some niches may be more demanding than others and speciation will occur at different rates.

\subsection{Starvation and VBNC cells}

The opinion exists that bacteria in the ocean are starved and do not grow (Morita 1985) or that at least they do not continuously (Kjelleberg et al. 1987). The experimental data that have led to these conclusions are mainly derived from studies involving the starvation survival response of copiotrophs. Most of the marine copiotrophic isolates that have thus far been investigated possess this starvation-survival strategy (Morita 1982, Amy \& Morita 1983). There is a wealth of information with respect to the different strategies that organisms exhibit to prolong survival during starvation. and the subject is well documented in various reviews (Dawes 1976, Morita 1982, 1985, 1988, Kjelleberg et al. 1987, Roszak \& Colwell 1987, Matin et al. 1989, Kaprelyants et al. 1993).

The decrease in viable cell count based on the ability to form colonies is one of the most obvious characteristics of the starvation-survival response. But, although this ability is lost, responsiveness to exogenous substrates is generally still present and counts of metabolically active cells are considerably higher than culturable counts. In such cases, cells are called dormant (Kaprelyants et al. 1993) or 'viable but nonculturable (VBNC)' (Roszak \& Colwell 1987). This issue was recently reviewed (Kaprelyants et al. 1993, Oliver 1993). Dormancy is observed in starved cultures of many copiotrophic bacteria (Calcott \& Postgate 1972, Postgate 1976, Reichardt \& Morita 1982, Xu et al. 1982, Amy \& Morita 1983, Baker et al. 1983, Kurath \& Morita 1983, Roszak et al. 1984, Rollins \& Colwell 1986, Barcina et al. 1989, Byrd \& Colwell 1990, Nilsson et al. 1991, Oliver et al. 1991, Kaprelyants \& Kell 1993, Preyer \& Oliver 1993).

The occurrence of VBNC cells in oceanic waters has been correlated with unculturability of indigenous 
bacteria (Oliver 1993). These cells are, by definition, 'incapable [of growth] on a medium normally supporting growth of that cell'. Such a formulation is, clearly, entirely based on laboratory data. It is presently clear that there is a relationship between starvation-survival and VBNC cells, but whether such cells play an important role in the open ocean has not been conclusively demonstrated (Oliver 1993). Yet, nonculturability of starved cultures and the unculturability of bacteria in seawater samples (ZoBell 1941, Jannasch \& Jones 1959, Kogure et al. 1980, Van Es \& Meyer-Reil 1982, Poindexter \& Leadbetter 1986, Roszak \& Colwell 1987, Austin 1988) together with the fact that in situ metabolic activity has been demonstrated in most indigenous cells (Meyer-Reil 1978, Zimmerman et al. 1978, Kogure et al. 1979, 1980, Tabor \& Neihof 1982, 1984, Douglas et al. 1987, Rodriguez et al. 1992) have led to the assumption that bacteria in the ocean are 'dormant' but not dead (Stevenson 1978, Morita 1985).

Not only does the presence of dormant cells have important consequences for public health (i.e. potentially pathogenic bacteria) (Xu et al. 1982, Rollins \& Colwell 1986), large-scale dormancy will also have great implications for the population dynamics of marine bacteria. Flagellates and ciliates consume small bacteria at significantly lower rates than larger bacteria, albeit with a difference in clearance rate of only a factor of 2 to 4 (Gonzalez et al. 1990). As a result, the autochthonous predatory population will eventually eliminate non-growing bacteria (McCambridge \& McMeekin 1981, Anderson et al. 1983). Therefore, dormancy as the basic physiological state of marine bacteria implies that 'pockets' of increased growth activity must exist that provide a steady supply of (dormant) cells. Such places may indeed be represented by nutritious aggregates, implying that epibacteria grow considerably faster than free-living cells. Although such 'breeding chambers' are likely to exist as a strategy in the life-cycle of copiotrophic cells in oligotrophic environments, the strategies and characteristics of truly low-nutrient-adapted dominant marine bacteria may be very different.

\subsection{Ultramicrobacteria from a new perspective}

As early as 1952, Oppenheimer (1952) found that some bacteria in seawater could pass through a $0.45 \mu \mathrm{m}$ membrane filter. These observations were confirmed by other researchers (Anderson \& Heffernan 1965, Hobbie et al. 1977, Tabor et al. 1981) and extended to $0.2 \mu \mathrm{m}$ membrane filters (MacDonell \& Hood 1982). The occurrence of $0.45 \mu \mathrm{m}$-filterable bacteria in groundwater has also been reported (Shirey \& Bissonnette 1991). Field studies have revealed that more than half (Watson et al. 1977) of the total bacterial population in seawater may consist of such 'ultramicrobacteria' as they were soon called (Torrella \& Morita 1981) and their abundance was correlated with low nutrient concentrations (Hood \& MacDonell 1987). Although many indigenous bacteria will pass a $0.45 \mu \mathrm{m}$ filter, few can pass a $0.2 \mu \mathrm{m}$ polycarbonate filter, and virtually none of the cells are able to pass a $0.22 \mu \mathrm{m}$ cellulose-nitrate filter, which, due to a channel-like pore-morphology, acts differently from the sieve-like polycarbonate filters. Given the fact that $0.2 \mu \mathrm{m}$ polycarbonate filters also contain larger pores due to overlapping, most individual bacterioplankton cells are potentially able to pass such filters. Using nominal filter pore-sizes for the definition of ultramicrobacteria is therefore not very practical. Since most cells are smaller than $0.1 \mu^{3}$ in cell volume (diameter < $0.3 \mu \mathrm{m}$ ) (Bjørnsen 1986, Lee \& Fuhrman 1987. Børsheim et al. 1990, Nagata \& Watanabe 1990), a better cell-size definition for ultramicrobacteria, and one that we propose, would consider a cell-volume of less than $0.1 \mu^{3}$ typical of such cells. This definition incorporates an important aspect of small cells: their low volume.

A characteristic starvation response known to occur in most bacterial isolates is miniaturisation of the cells (Morita 1985) as a result of which the surface to volume ratio is increased. Many bacteria tend to 'round up' during starvation (Tabor et al. 1981, Baker et al. 1983), and form spheroplasts (Reichardt \& Morita 1982), 'dwarf' cells (Dawson et al. 1981), 'round bodies' (Felter et al. 1969) or 'ultramicrocells' (Hood \& MacDonell 1987). Interestingly, the cell size of starved marine isolates is comparable to that of the indigenous marine bacterioplankton (Novitsky \& Morita 1976, 1977, 1978, Moyer \& Morita 1989). The addition of nutrients to seawater samples results in the emergence of large cells, or an increase in mean cell volume, and an increase in nutrient uptake rates (Wright 1978). Several investigations have demonstrated that some filterable (ultramicro)bacteria from seawater can revert to normal (large)-sized cells of identifiable taxa when provided with the appropriate nutrients (Anderson \& Heffernan 1965, Tabor et al. 1981, MacDonell \& Hood 1982). As a result of such studies it was concluded that the small indigenous cells represent starved forms of known species of bacteria (Stevenson 1978, Morita 1982, 1985, Kjelleberg et al. 1987, Roszak \& Colwell 1987). However, the viable count of filterable (ultramicro)cells, and thus the percentage of ultramicrobacteria isolated and identified in this way, was less than $0.01 \%$ of the total direct count in the cases reported (Anderson \& Heffernan 1965, Tabor et al. 1981, MacDonell \& Hood 1982). The true nature of ultramicrobacteria is therefore basically unknown. 
Ultramicrobacteria that do not increase in size upon the addition of nutrients have frequently been observed (Anderson \& Heffernan 1965, Hamilton et al. 1966, Ishida \& Kadota 1981, Torrella \& Morita 1981), but, as stated by Kjelleberg et al. (1987), their presence has largely been ignored. Therefore, the occurrence of ultramicrobacteria in the ocean is not necessarily always the result of starvation. Some of the arguments to support this view are listed below.

(1) Azam \& Fuhrman (1984) proposed that dormancy as an adaptive strategy is not eminently necessary for bacteria in the euphotic zone since the time-frame of unfavourable conditions is often limited to hours. (2) Bacteria of ultramicrobacterial size that remain small when actually growing have been encountered (Hamilton et al. 1966, Ishida \& Kadota 1981, Carlucci et al. 1987, Gonzalez et al. 1990, Schut et al. 1993). (3) There is evidence that on a per volume basis, the smaller cells are much more active than the larger bacteria (Fuhrman 1981, Lee \& Fuhrman 1987, Button \& Robertson 1989). (4) Short-term starvation in Pseudomonas aeruginosa and Streptococcus cremoris results in rapid equilibration of intracellular and extracellular amino acid pool concentrations (Kay \& Gronlund 1969 . Poolman et al. 1987), whereas in planktonic bacteria concentration gradients of $10^{6}$-fold are maintained with 'normal' intracellular levels in the millimolar range (Simon \& Azam 1989). (5) From an early compilation of data on bacterial production measured by thymidine incorporation (Azam \& Fuhrman 1984) it was concluded that in situ growth rates in coastal regions averaged 0.01 to $0.09 \mathrm{~h}^{-1}$ Such values have also been obtained more recently (Iriberri et al. 1990). For pelagic regions, bacterial production rates equivalent to in situ growth rates of $0.01 \mathrm{~h}^{-1}$ have been reported (Yoshinaga et al. 1991) and more than $90 \%$ of this productivity is due to free-living cells (Cho \& Azam 1988; see also Section 1.4). Moreover, it has been shown that in oligotrophic environments, amino acid incorporation rates (protein synthesis) are significantly higher than thymidine incorporation rates (DNA synthesis) (Kirchman et al. 1986, Douglas et al. 1987. Yoshinaga et al. 1991), suggesting unbalanced growth in the indigenous bacteria. Such discrepancies are not observed in eutrophic regions (Tabor \& Neihof 1982, Fuhrman \& Azam 1982). Thus, macromolecular synthesis in oligotrophic regions does not necessarily coincide with cell division and growth rate measurements should be interpreted carefully.

In summary, it cannot be concluded that marine bacteria are inactive. There is also no indication that they exhibit the greatly reduced activity encountered in starved or dormant marine bacterial isolates. Finally, small cells are not necessarily starved. Growth and metabolism of free-living bacteria in oligotrophic regions constitute an important global process

\subsection{Enrichment and isolation of ultramicrobacteria}

That naturally occurring marine bacteria are able to grow in unamended, filtered and autoclaved, natural seawater (FAS) has long been known (Hamilton \& Carlucci 1966, Hamilton et al. 1966, Jannasch 1967. Ammerman et al. 1984, Hagström et al. 1984, Li \& Dickie 1985). Since it cannot be excluded that significant alterations in the nutritional composition occur during experimental handling of seawater (Ferguson et al. 1984), the results of growth experiments with seawater inocula in FAS provide no real evidence for the occurrence of growth under natural conditions. However, conditions are probably as close to natural as one can get and may be most suitable for the enrichment of dominant cells.

The dilution culture technique described by Button et al. (1993) and Schut et al. (1993) presents a suitable method to obtain such enrichments. A relatively large fraction, typically close to $50 \%$, of the indigenous population was able to grow in dilution tubes that contained FAS (Button et al. 1993). Besides the 'normal', large bacteria, very small bacteria with small genomes grow in such dilution tubes. These ultramicrobacteria, which are typical representatives of the indigenous, free-living seawater bacteria, are outgrown by larger, fast-growing cells if the number of inoculated cells in such tubes is too high, i.e. if the dilution factor is too low. Generally, dilution factors that result in inocula of approximately 2 cells per tube are optimal to obtain sufficient tubes that contain bacterial cultures while preventing outgrowth of atypically large bacteria.

None of the cultures enriched via this dilution-culture technique and containing ultramicrobacteria could be cultivated directly onto nutrient-rich agar media. The larger, fast-growing cells that developed principally in 'low dilution or high cell-density inoculum' cultures grew readily on such media. During the early stages of cultivation and subcultivation, ultramicrobacteria could only be cultivated in FAS, or in synthetic seawater containing less than $1 \mathrm{mg}$ amended substrate $\mathrm{C}^{-1}$. According to the definition of Ishida et al. (1989) in Table 1, the ultramicrobacteria should be considered obligately oligotrophic, and the larger cells as facultatively oligotrophic. Most interestingly, storage of stationary phase cultures of ultramicrobacteria for several months at $5^{\circ} \mathrm{C}$ triggered a process by which the cells developed the ability to grow on high-nutrient media, transforming the cells into facultative oligotrophs (Schut et al. 1993). At present, the nature of this transformation is unclear. 
Since almost every individual cell within such starved dilution cultures was able to develop colonies on highnutrient media, a unique mutation is not a likely explanation. Nor can it easily be explained by regrowth of a few cells that used the nutrients released by moribund or dead cells (Oliver 1993) since this would have resulted in lower cell densities upon transformation (considering that no alteration in cell volume was observed). This isolation procedure for dominant marine (ultramicro)bacteria, including the starvation step, was shown to be fully reproducible with samples from North Sea water.

What mechanism could then serve as an explanation for this transition? We believe that the complete adaptation or conditioning of the cells to their low-nutrient cnvironment may hold the answer Strain RB2256 (Schut et al. 1993), one of the ultramicrobacteria isolated by this dilution culture technique and tentatively identified as a marine Sphingomonas sp. (Schut 1994, Schut unpubl.), was investigated in more detail (Schut 1994, Schut et al. 1995). Although no marked difference in substrate uptake affinity for either alanine or glucose was found between cells of this strain grown under nutrient-limitation or in batch culture, a general decrease in the substrate uptake affinity of glucose (Schut 1994) and alanine (authors unpubl. obs.) occurred during starvation. Most interestingly, Sphingomonas sp. strain RB2256 was found to be almost completely unable to grow on high-nutrient, complex agar media when grown under substrate limitation in chemostat (Schut 1994, Eguchi et al. 1996). Although such observations have also been reported for Cytophaga johnsonae (Höfle 1983, Van Gemerden \& Kuenen 1984), the extent of the phenomenon in Sphingomonas sp. strain RB2256 is orders of magnitude larger than in bacteria investigated thus far. The spread-plate viability of glucose-limited cells is often below $0.01 \%$ on high-nutrient complex media. On low-nutrient complex media and on high-nutrient defined (glucose) media, however, cells are readily culturable. This may be analogous to the observation of Martin \& MacLeod (1984; see Section 3.1) that the ability to utilise substrates at specific concentrations strongly depends on whether substrates are supplied as single substrate or as complex mixtures.

While high substrate affinities are believed to prevent growth of bacteria at high substrate concentrations through a mechanism named 'substrate accelerated death' (Höfle 1984), a lowering of the uptake affinity may prevent this from happening. If this also results in the ability of cells to grow on high-nutrient, complex media, an obligately oligotrophic phenotype may be a side-effect of the possession of stupendous substrate affinities. Sphingomonas sp. strain RB2256 has just that!

\section{THE BLUEPRINT FOR DOMINANT MARINE BACTERIA}

\subsection{General response to nutrient limitation}

In 1979 the Dahlem conference on 'life under conditions of low nutrient concentrations' resulted in a list of physiological and morphological characteristics that would suit a typical oligotrophic bacterium (Hirsch et al. 1979). This 'model oligotroph' was the blueprint for a bacterium that would contain the 'state of the art' machinery to cope with the open oceans' environmental conditions. Since that time, much physiological work has been done, mainly in chemostats in which the level and type of nutrient limitation could be controlled. It is important to note that almost all such work was performed with 'copiotrophic' bacteria.

The normal physiological response to nutrient limitation found in most bacteria investigated in such studies include (1) an economisation in the use of the limiting nutrient, (2) an increase in the rate of initial metabolism, or (3) an increase in the nutrient uptake capacity (Harder \& Dijkhuizen 1982, 1983, Harder et al. 1984). The first reaction requires reduction of those metabolic fluxes that lead to metabolites containing the limiting nutrient and results in a change in chemical composition of the cell. The second response requires derepression of the synthesis of catabolic enzymes. The half-saturation constant of many of these enzymes for their substrate is in the millimolar range. This low affinity can be compensated by higher activities, or higher concentrations, of the catabolic enzymes involved in the initial metabolism. In this way, low intracellular concentrations of accumulated substrate can still be metabolised at high rates. Alternatively, highaffinity catabolic enzymes may be synthesised (Harder et al. 1984, and references therein). The third response to nutrient limitation involves changes in the transporter properties. Synthesis of transport systems can be increased so that more substrate binding sites are formed. This increases the chance of an actual collision between substrate and transporter molecule (Button 1993). Alternatively, induction of high affinity systems with lower affinity constants may occur.

\subsection{Mechanisms of substrate accumulation}

Cytosolic pool concentrations of metabolites in actively growing cells are generally in the millimolar range, while ambient concentrations of substrates in nature are in the micro- to nanomolar range. Many substrates are therefore accumulated into the cell against an enormous concentration gradient. The free energy of ATP hydrolysis can concentrate solutes 
against a $10^{5}$-fold gradient (Konings et al. 1989). An important advantage of these systems is that they are unidirectional, in contrast to proton-motive-force (pmf) driven systems that can function in both directions (Konings et al. 1989). This means that substrate accumulation levels are better retained in the absence of metabolic energy, which has important consequences for cells in oligotrophic environments that live on the verge of starvation. In most copiotrophic cells investigated, a rapid dissipation of the pmf is observed upon exhaustion of energy resources (Konings \& Veldkamp 1983, Poolman et al. 1987). If uptake of important energy-generating substrates would solely depend on the presence of a pmf, the organism would most probably die even when substrates eventually become available (Konings \& Veldkamp 1983). One group of transport ATP-ases is composed of binding-proteindependent transport systems (Higgins et al. 1990). These protein complexes are typically formed by a periplasmic substrate-binding protein and 3 membrane-bound components. Binding-protein-dependent transport systems have been found for many different substrates and in many marine bacteria (Furlong 1987). Oligotrophic bacteria would most likely possess this type of substrate transporter.

\subsection{Uptake kinetics and mixed substrate utilisation}

Whereas the maximum attainable accumulation level of substrates in cells can be predicted from thermodynamic formulations, predictions on growth rates are largely based on kinetic formulations that were empirically derived (Monod 1950). Whether substrates are taken up at rates sufficient for growth depends on the kinetic parameters of all enzymes involved and on the amount of substrate required per unit biomass (Button 1985, 1991). Apart from the association rate between external substrate and transporter binding site, which in oligotrophic habitats will largely depend on the concentration of these sites on the cell surface, the rate at which the substrate is passed on to interior pools, and thus the rate at which the transport system is ready to bind a new substrate molecule, is crucial (Button 1991).

Uptake and assimilation kinetics can be described by the traditional Michaelis-Menten relationship

$$
v=\left(V_{\max } \times A_{\text {out }}\right) /\left(K_{\mathrm{t}}+A_{\text {out }}\right)
$$

in which $v$ is the specific uptake rate expressed per unit of biomass, $V_{\max }$ is the maximum specific uptake rate at saturating $[A], A_{\text {out }}$ is the external substrate concentration, and $K_{\mathrm{t}}$ is the whole-cell Michaelis constant for transport. The initial slope of the $V / A_{\text {out }}$ curve expresses the capacity of an organism to effectively capture and utilise substrates from dilute suspension and equals $V_{\max } / K_{\mathrm{t}}$. Thus, the ability of an organism to capture a given substrate at very low concentrations, while accumulating it at sufficient rates to allow for growth, depends on both the maximum attainable rate and the half-saturation constant (Button 1991).

It should be noted that the half-saturation constant for substrate uptake alone gives no information as to whether that substrate is accumulated at sufficient rates. Generally little attention is paid to this fact in studies on the kinetic properties of marine bacteria. Carlucci et al. (1986) proposed that oligotrophs should have $K_{1}$-values below $10 \mathrm{~g} \mathrm{C} \mathrm{l}^{-1}$. However, if this results in infinitesimal rates of uptake, growth will be so slow that maintenance requirements cannot even be met (see strain LN-155; Table 3). The resulting threshold concentrations of external substrate that are required by indigenous marine bacteria are not known. For known bacterial isolates, these values can range from $<0.03$ to $18 \mathrm{~g}$ of substrate $\mathrm{l}^{-1}$ and can strongly depend on the presence of other utilisable substrates (Law \& Button 1977, Button 1985). Table 3 summarises the growth abilities of some marine bacteria at external substrate concentrations of $1 \mathrm{~g} \mathrm{l}^{-1}$. In the calculation of the doubling time, $t_{\mathrm{d}}$, maintenance requirements are not accounted for.

In order to conserve protein, oligotrophic cells may devote relatively more material to biosynthesis of transporters than to other functions (Button 1991). Since the flux of nutrients in oligotrophic habitats is extremely low, small amounts of cytoplasmic enzymes can process the nutrients usually accumulated. This results in a situation where the uptake capacity can by far exceed the maximum metabolic rate. Considering that cytoplasmic enzyme levels are fully derepressed under oligotrophic conditions (Harder \& Dijkhuizen 1982, 1983), cytosolic pool levels may become so excessively high in the case that external substrate concentrations approach saturation levels for uptake that impairment of growth is a conceivable consequence (Button 1991). This mechanism may well explain the observation that marine bacteria are able to grow at ambient concentrations of nutrients, but not in the presence of several micromolars of utilisable substrates (Akagi et al. 1977, Button 1991, Yoshinaga et al. 1991, Schut et al. 1993). A parallel may be drawn with the suggested 'limited elasticity' of oligotrophic bacteria (Van Gemerden \& Kuenen 1984) due to their extremely accurate control of the biosynthetic protein content relative to the amount of membrane (high surface to volume ratio). Whether marine indigenous bacteria indeed exhibit such regulatory inabilities is still unknown, but populations of oligotrophic bacteria are likely to be very vulnerable to sudden shifts in the quality and quantity of available nutrients. 
Table 3. Michaelis-Menten constants and calculated in situ doubling times of some bacterial strains isolated from marine sources (recalculated from Table 5 in Schut et al. 1993)

\begin{tabular}{|c|c|c|c|c|}
\hline Organism & Substrate & $K_{\mathrm{t}}^{\mathrm{*}}$ & $t_{\mathrm{d}}{ }^{\mathrm{b}}$ & Source \\
\hline Sphingomonas sp. strain RB2256 & DFAAs & 0.2 & $12 \mathrm{~h}$ & Schut et al. (1993) \\
\hline Strain GL-7 & Glucose & 0.08 & $5 \mathrm{~d}$ & Hamilton et al. (1966) \\
\hline Sphingomonas sp. strain RB2256 & Alanine & 1.3 & $31 \mathrm{~d}$ & Schut et al. (1995) \\
\hline Serratia marinorubra & Glucose & 6.4 & $51 \mathrm{~d}$ & Hodson \& Azam (1979) \\
\hline Vibrio sp. S14 & Glucose & 4.6 & $60 \mathrm{~d}$ & Albertson et al. (1990) \\
\hline Corynebacterium sp. 198 & Glucose & 2.67 & $74 \mathrm{~d}$ & Button (1985) \\
\hline Pseudomonas sp. 486 & Proline & 0.2 & $137 \mathrm{~d}$ & Akagi \& Taga (1980) \\
\hline Vibrio sp. S14 & Leucine & 0.76 & $215 \mathrm{~d}$ & Mărdén et al. (1987) \\
\hline Sphingomonas sp. strain RB2256 & Glucose & 15 & $1 \mathrm{yr}$ & Schut et al. (1995) \\
\hline Pseudomonas sp. RP-303 & Proline & 1.8 & $2 \mathrm{yr}$ & Akagi \& Taga (1980) \\
\hline Pseudomonas sp. 486 & Glucose & 13.0 & $3 y r$ & Akagi \& Taga (1980) \\
\hline Vibriosp. ANT-300 & Arginine & 4.6 & 9 yr & Geesey \& Morita (1979) \\
\hline Alteromonas haloplanktis & Alanine & 46 & $9 \mathrm{yr}$ & Fein \& MacLeod (1975) \\
\hline Strain LN-155 & Glucose & 0.18 & $27 \mathrm{yr}$ & Nissen et al. (1984) \\
\hline Pseudomonas sp. RP-303 & Glucose & 3.6 & 32 yr & Akagi \& Taga (1980) \\
\hline
\end{tabular}

\section{4. 'Oligotrophic' qualifications}

Several very low $K_{1}$ uptake systems have been found in marine isolates (Hamilton et al. 1966, Geesey \& Morita 1979, Akagi \& Taga 1980, Nissen et al. 1984). However, the reported $V_{\max }$-values are also generally so low that specific affinities (Button 1993) are insufficient to allow growth at realistic generation times in the ocean at the expense of a single substrate. When consumed simultaneously, however, the ambient level of substrates could provide bacteria with enough carbon and energy for growth at more realistic rates.

The ability to utilise multiple substrates simultaneously under growth-rate-limiting substrate concentrations is a common trait of most known bacterial species (Harder \& Dijkhuizen 1982, Gottschal \& Dijkhuizen 1988, Gottschal et al. 1992) and often simply involves the derepression of uptake and utilisation pathways. In the marine Pseudomonas sp. strain T2, the presence of amino acids can enhance the uptake of glucose and lower its threshold concentrations for growth (Law \& Button 1977). Organisms able to grow in the open ocean would ideally exhibit simultaneous multiple substrate utilisation abilities together with a broad substrate spectrum. Literature data are not conclusive about the substrate spectrum of oligotrophic bacteria, since both broad (Upton \& Nedwell 1989) and narrow (Eguchi \& Ishida 1990) substrate utilisation spectra have been reported and discussed as being advantageous for oligotrophic bacteria. Transporter specificity may indeed generally be lower in oligotrophs (Akagi \& Taga 1980).
The new marine isolate Sphingomonas sp. strain RB2256 (Schut et al. 1993, 1995) exhibits specific uptake affinities for mixed amino acids that allow for realistic in situ generation times (Table 3 ; see also Schut et al. 1995). The glucose uptake system in this organism is inducible and exhibits a narrow substrate specificity. Since half-saturation constants for glucose were relatively high (between 7 and $74 \mu \mathrm{M}$ ) it is unlikely that glucose is an important natural growth substrate for these cells. On the other hand, the alanine uptake system is constitutively expressed and is binding protein dependent. In addition to L-alanine, 9 other amino acids can completely inhibit the accumulation of $\left[{ }^{14} \mathrm{C}\right]$-L-alanine, indicating broad substrate specificity of the alanine transporter. With half-saturation constants between 1.3 and $1.8 \mu \mathrm{M}$ and high maximum attainable uptake rates, RB2256 exhibits the highest uptake affinity ever reported for alanine (Schut et al. 1995). Simultaneous uptake and utilisation of many amino acids is possible during growth on alanine and detailed studies on the utilisation of mixed amino acids may reveal new insights into how these cells live in nature. Simultaneous utilisation of glucose and alanine occurs during substrate-limited growth, as well as during batch culture growth at relatively high (mM) substrate concentrations. On the basis of these studies, we concluded that mixed substrate utilisation is an inherent property of this organism, and that amino acids are potentially important growth substrates in nature.

Some other characteristics of this bacterium are also worth studying. For example, cells of Sphingomonas 
Table 4. Summary of characteristics of Sphingomonas sp. strain RB2256

Isolated by dilution-to-extinction (present in relatively high numbers)

Little variation in cell volume $\left(0.05\right.$ to $\left.0.09 \mathrm{~m}^{3}\right)$

Low DNA content $\left(1.0\right.$ to $\left.1.7 \mathrm{fg} \mathrm{cell}^{-1}\right)$

Rich in protein $\left(>800 \mathrm{mg} \mathrm{ml}^{-1}\right.$ cell volume: $>60 \% \mathrm{vol} / \mathrm{vol}$ )

Low rRNA operon number ( 1 copy; R. Cavicchioli pers comm.)

Facultatively oligotrophic, obligately oligotrophic upon first cultivation

Constitutive binding-protein-dependent 'general' amino acid uptake system

Extremely high alanine uptake affinity with high maximum attainable rates

Well adapted to simultaneous substrate utilisation

Potentially able to grow in the ocean at realistic rates

Internal storage of glucose during glucose-limited growth

Extremely stress resistant; both growing and starved cells

Absence of typical starvation-survival response sp, strain S14) that have been obtained from the culturable fraction of seawater are atypical, quite large, fast-growing organisms that are only likely to exhibit significant metabolic activity in coastal eutrophic waters or when attached to nutritious detritus. Most of our knowledge on aquatic and marine bacteria is restricted to such species that form a numerical minority in natural populations. But it is becoming clear that the marine bacterioplankton is not dominated solely by the $\gamma$-subclass of Proteobacteria to which the 3 above-mentioned

sp. strain RB2256 are extremely resistant to various stress-inducing agents. High survival rates are observed after heat-shocks of up to $56^{\circ} \mathrm{C}$, treatments with $25 \mathrm{mM} \mathrm{H}_{2} \mathrm{O}_{2}$ and with $20 \%$ ethanol. Most importantly, there is no marked difference between starved and actively growing cells, particularly so with chemostatgrown cells (Eguchi et al. 1996). This, as well as the lack of miniaturisation, the decrease in substrate uptake affinity and the rapid decrease in culturability upon starvation, indicates that this strain lacks the characteristic starvation-survival pattern and may consequently not be well adapted to such conditions. The ability of Sphingomonas sp. strain RB2256 to grow on high-nutrient media is unexpected and may be the result of adaptation to laboratory conditions. Its inability to grow on such media should perhaps be considered normal, emphasising that VBNC as an anomalous state of otherwise normal bacteria does not apply to these cells (Table 4).

The combined traits of Sphingomonas sp. strain RB2256 strongly suggest that this cell type plays an important role in the ocean. Characteristics point towards a free-living (pelagic) life-strategy but molecular techniques will have to prove whether indeed these cells represent a dominant part of the unculturable fraction of seawater.

\section{MOLECULAR CHARACTERISATION OF MARINE PELAGIC BACTERIA}

\subsection{The scientific need to cultivate indigenous marine bacteria}

The 'unculturability' of marine bacteria has intrigued scientists for at least half a century (MacLeod 1985). Solid agar media have proven inadequate to cultivate the dominant cells in aquatic environments. Isolates such as Alteromonas haloplanktis (Pseudomonas B-16), Vibrio sp. strain ANT300 or Vibrio proteolyticus (Vibrio \& Giovannoni 1991, Schmidt et al. 1991). Rather, $\gamma$-subclass Proteobacteria seem to selectively dominate aquatic culturable fractions (Wagner et al. 1993) and aggregate-attached populations (DeLong et al. 1993). Although it would be incorrect to dismiss studies on these bacteria as being non-relevant - these types of bacteria may be of great importance in solubilising particulate organic carbon (Cho \& Azam 1988) - there is ample evidence for the presence of large numbers of new, undiscovered species, mainly of the $\alpha$-proteobacterial lineage that have yet to be isolated, cultivated and physiologically investigated.

Primarily, this evidence is based on molecular ecological techniques such as the direct extraction of nucleic acids from the environment. The use of DNA hybridisation techniques in microbial ecology now enables researchers to recognise individual cells of defined taxonomic level in situ (Giovannoni et al. 1988, Stahl et al. 1988, Amann et al. 1995) even if these bacteria have never been cultivated in the laboratory. In this way, population dynamics can be studied in situ. The developments in molecular probing look so promising that they have created the impression of completely eliminating the need for cultivation in the future. Already, research on the biodegradation of xenobiotics, agricultural and food fermentation processes, treatment of wastewater and gas, risk assessment of the release of genetically modified microorganisms (GMMs) as well as medical microbiological research benefit greatly from these developments.

Yet, although immunolabels and probes can even be targeted to specific enzymes and mRNAs, such labels cannot be developed against targets whose nature is yet unknown. The enormous natural diversity of microorganisms does not easily allow for predictions on how such probes perform in hitherto unknown organisms. Therefore, the exact validation of a probe requires testing under controlled conditions, preferably with the organism of interest itself and basic insight into the species and most other plate isolates belong (Britschgi 
physiological properties of bacteria can thus not be revealed solely by in situ techniques. Autecological studies in microbiology require the extraction of individual strains from their natural environment as pure cultures before the ecological significance of such a strain, expressed as its physiological behaviour under simulated natural conditions, can properly be investigated and understood. Physiological research (still) requires investigation of high cell-density pure cultures and cultivation of organisms will therefore always remain necessary especially in conjunction with molecular in situ probing techniques.

\subsection{Diversity of marine bacteria based on $16 \mathrm{~S}$ rDNA data}

The vast amount of data proving that most bacteria in seawater are active but unculturable (Roszak \& Colwell 1987, Rodriguez et al. 1992) provides an impulse for the development of alternative methods to investigate the distribution, diversity and physiology of indigenous marine bacteria. Soil and freshwater microbiologists are confronted with similar problems. The 3300 validly described prokaryotic (non-cyanobacterial) species only represent a tip of the iceberg of the estimated more than 1 million prokaryotic species that inhabit our planet (Stackebrandt \& Rainey 1995). In recent years, marine bacterioplankton of various origins has been characterised phylogenetically based on 16S rRNA sequences (Giovannoni et al. 1990, Britschgi. \& Giovannoni 1991, Schmidt et al. 1991). The results have demonstrated that many bacteria present in seawater cannot be assigned to known species. Additional studies on restriction fragment length polymorphism (Britschgi \& Giovannoni 1991) have revealed that $18 \%$ of the clones obtained via shotgun-cloning of DNA extracted from Sargasso Sea water samples belong to a group of organisms closely related to Roseobacter denitrificans (formerly Erythrobacter OCh114) and another $18 \%$ belongs to the so-called SAR11 cluster (Giovannoni et al. 1990). The SAR11 cluster is comprised entirely of thus far uncultured bacteria that form a very deep phylogenetic branch within the $\alpha$-proteobacterial lineage. Independent investigations have confirmed the presence of this evidently important and unique group of bacteria of which only $16 \mathrm{~S}$ rDNA sequences are known. Such methods have opened the way to identification and exploration of marine bacteria. The appearance of the first results on quantitative analysis by using in situ hybridisation with DNA probes, necessary to understand the distribution, contribution and role of particular species (Liesack \& Stackebrandt 1992), thus seems only a matter of time. Knowledge of the phylogenetic affiliation of uncultur- able bacteria can directly aid in the selection of proper media for their isolation (Liesack \& Stackebrandt 1992 Wagner et al. 1993), may help in understanding the phenomenon of unculturability, and set the background for studying the physiology of indigenous freeliving marine bacteria.

16S rRNA hybridisation probes have proven applicable in many ecosystems such as soil (Hahn et al. 1992), hot springs (Ward et al. 1990), biofilms (Amann et al. 1992), intestinal tracts (Hensiek et al. 1992), and activated sludge (Wagner et al. 1993, for a review see Amann et al. 1995). It was suggested that ultramicrobacteria such as Sphingomonas sp. strain RB2256 can attribute between 15 and $35 \%$ of the bacterioplankton community of Resurrection Bay near Seward, Alaska, USA (Schut et al. 1993). To test this hypothesis, fluorescent $16 \mathrm{~S}$ rRNA-targeted hybridisation probes were developed for this strain (Schut 1994, Schut unpubl.). Thus far, none of the wide geographical range of seawater samples tested with these probes revealed bacteria with fluorescence signals above the background level, suggesting either that RB2256 was not present in these samples or that the ribosome content of naturally occurring bacteria is too low to reveal sufficiently high fluorescence signals of (FITC) monolabelled probes. Use of non-selective bacterial $16 \mathrm{~S}$ rDNA probes indeed indicated the latter to be the case. Insufficient fluorescent signals from natural populations of bacteria hybridised in situ with 'universal' or 'bacterial' rRNA-targeted probes have been reported previously (Hahn et al. 1992, Hicks et al. 1992) and have been attributed to low intracellular amounts of $16 \mathrm{~S}$ rRNA molecules as a result of low in situ growth rates (Kemp et al. 1993, Kerkhof \& Ward 1993). To increase the low signal in natural seawater samples, we performed PCR amplification of eubacterial $16 \mathrm{~S}$ rDNA sequences from extracted 'community DNA' as an initial enrichment step followed by Southern hybridisation with a digoxigenin-labelled version of the Sphingomonas sp. strain RB2256-specific probe. In this way, the presence of the target sequence among $16 \mathrm{~S}$ rDNA fragments amplified from seawater taken from the site of isolation of this strain was indeed demonstrated (Schut 1994), supporting the need for enhanced fluorescent signals in the future use of fluorescent, whole-cell in situ hybridisation probes in ecological studies. Methods to overcome these technical limitations have recently been proposed and reviewed (Amann et al. 1995). By using CCD cameras and digital image analysis in combination with a universal probe, Fuhrman et al. (1994) recently obtained distinguishable signal from $75 \%$ of the cells in their sample while about $25 \%$ of the population remained indistinguishable from background. By this method, they could demonstrate that Archaea make up $6 \%$ of the 
total population present in investigated samples. By using the same technique, Ramsing et al. (1996) could detect only half of the DAPI-stained population by uni versal $16 \mathrm{~S}$ rRNA probe-staining.

\subsection{Phylogenetic position of ultramicrobacteria, oligotrophs and marine clones}

Molecular evolutionary studies rely on the correct interpretation of sequence data. Sequence alignment, choice of sequence regions included in the analysis and the extent of the reference database are important factors. The presence of higher order structures (helices formed by inverse complementary stretches) helps to establish correct alignment of ribosomal RNAs of diverse taxonomic origin. This step is crucial since it determines the quality of phylogenetic trees derived from sequence data. Whether regions should be included or excluded from analyses is determined by the usefulness of their phylogenetic information and their reliability. Hyper-variable regions may be the only regions that contain differences when closely related taxa are analysed. Although their phylogenetic importance is debatable (Stackebrandt \& Rainey 1995), such regions are still the main targets for the fluorescence in situ hybridisation (FISH) probes with which individual cells can be identified.

It is important to point out that classifications based on metabolic and/or phenetic criteria, while useful for other reasons, are probably the least suitable for phylogenetic classification of proteobacteria. This is because physiological properties have arisen in parallel many times within this phylum (Stackebrandt 1985) and thus provide little or no phylogenetic information. Using molecular-based trees in tandem with physiological data, one can draw general inferences about the origin of oligotrophy and other physiological properties of interest. On the basis of our studies (Schut 1994), Sphingomonas sp. strain RB2256 shows no affiliation to the SAR11 cluster of Giovannoni et al. (1990). Also, 16S probes specific for the SAR11 cluster did not hybridise to the DNA of Sphingomonas sp. strain RB2256 (S. J. Giovannoni pers, comm.). Nevertheless, it is to be expected that the physiological adaptations to growth in the open ocean might be similar. Such questions can be assessed only after many more representative pelagic marine bacteria have been successfully cultured.

So far, few of the seawater isolates show affiliation to dominant $16 \mathrm{~S}$ rDNA clones obtained from seawater. Free-living fractions often seem to be dominated by SAR11-type bacteria [Giovannoni et al. 1990, Schmidt et al. 1991, DeLong et al. 1993, see also Mullins et al. 1994 (SAR clones), (POR and PLY clones; Gen Bank
Entry U 13155, unpubl.), and Fuhrman et al. 1993 (NH49 and BDA1 clones)] that also seem to be represented in the seawater sediment (Gen Bank Entry U 09829, unpubl.). Interestingly, some of the plate isolates obtained by Rehnstam et al. (1993), that sometimes formed a dominant part of the indigenous population, were said to be closely related to clone ALO29 of Schmidt et al. (1991), whereas other isolates show more affiliation to the marine snow associated clone AGG50 of DeLong et al. (1993). It is evidently the combination of genetic studies and cultivation experiments that will create a new vista on the nature of pelagic marine bacteria in general and their physiological state under natural conditions in particular.

\section{CONCLUDING REMARKS AND UNANSWERED QUESTIONS}

Indigenous marine bacteria are of eminent importance to global nutrient cycling. Typically, native cells that are of ultramicrobacterial dimensions appear not to be associated with aggregates and may have truly remarkable abilities for substrate capture. In many respects, they are different from the cells that have hitherto been isolated from oceanic waters. Their cellular identity, nevertheless, remains largely unknown. It is recognised that small free-living marine bacteria are actively metabolising but virtually none of them have ever been grown in the laboratory. It seems inevitable that these cells are actively growing in nature. Although many studies have shown that low molecular weight substances are taken up and metabolised by natural seawater samples, it should be realised that the growth substrates of indigenous bacteria are presently not well defined

Furthermore, it remains unknown why the majority of indigenous cells cannot be cultivated. The marine bacteria that have thus far been isolated exhibit great flexibility to changes in nutrient availability. If this flexibility forms the basis for their culturability, it may be reasoned that the majority of marine bacteria cannot adapt to such changes possibly because they never really encounter large fluctuations. It is therefore most conceivable that free-living marine bacteria represent cells with a remarkably stable 'low-nutrient-conditioned' phenotype. Often, this is perceived as an obligately oligotrophic state.

Without attempting to add yet another comprehensive definition of oligotrophy to the long list of existing definitions, it is perhaps this very lack of flexibility and short-term adaptability with respect to growth in the presence of substrate concentrations several-fold higher than ambient which is most characteristic for the oligotrophic way of life. 
Hence, oligotrophy rather represents a set of physiological traits, in many different species, all geared to efficiently deal with an extremely limited supply of nutrients, whatever they may be, and within any type of environment. Formulated in this way, particular organisms could be oligotrophic with respect to some nutrients and not to others. Moreover, this may also imply that certain 'oligotrophs' be isolated from 'eutrophic' environments simply because they are oligotrophic with respect to a particular set of nutrients, poorly available in that particular environment. Of course then it is not surprising to find that marine pelagic ecosystems will predominantly harbour microorganisms which are oligotrophic for almost any substrate as this would usually reflect precisely the general nutrient scarcity in the ocean.

Evidently, agar media are not suited to isolate the dominant part of the bacterioplankton. Cultivation by extinction-dilution provides a more reliable method to obtain cultures of cells that form a numerically important fraction of the bacterioplankton population. The availability of Sphingomonas sp. strain RB2256, isolated by this procedure, may give impetus to the physiological characterisation of indigenous marine bacteria. It should be emphasised that such isolates have accomplished a significant transformation once able to grow to high cell densities. Such cell densities bear little or no relevance to the oceanic situation. The adaptation required for detailed physiological study masks the original phenotype. This vicious circle has not yet been broken.

Molecular biological techniques have transformed microbial ecology into an exciting new multidisciplinary science. However, there is a danger that such techniques become a research goal in themselves, thereby limiting the scope of ecological studies. The high-tech nature of the molecular approach makes the more conventional ecophysiological approaches look ancient. However, without the impact of an 'ancient' technique like the agar plate isolation procedure, microbiology would probably never have evolved to its current status and would experience a hard time moving forward. The symbiosis of the 2 approaches is the only feasible way to solve the puzzle of microbial growth in the ocean.

\section{LITERATURE CITED}

Akagi Y, Simidu U, Taga N (1980) Growth responses of oligotrophic and heterotrophic marine bacteria in various substrate concentrations, and taxonomic studies on them. Can J Microbiol 26:800-806

Akagi Y, Taga N (1980) Uptake of D-glucose and L-proline by oligotrophic and heterotrophic marine bacteria. Can J Microbiol 26:454-459
Akagi Y, Taga N, Simidu U (1977) Isolation and distribution of oligotrophic marine bacteria. Can J Microbiol 23:981-987

Albertson NH, Nystrom T, Kjelleberg S (1990) Starvationinduced modulations in binding protein-dependent glucose transport by the marine Vibrio sp. S14. FEMS Microbiol Lett 70:205-210

Alldredge AL (1979) The chemical composition of macroscopic organic aggregates in two neritic seas. Limnol Oceanogr 24:855-866

Alldredge AL, Silver MW (1988) Characteristics, dynamics, and significance of marine snow. Prog Oceanogr 20:41-82

Amann RI, Ludwig W, Schleifer KH (1995) Phylogenetic identification and in situ detection of individual microbial cells without cultivation. Microbiol Rev 59:143-169

Amann RI, Stromley J, Devereux R, Key R, Stahl DA (1992) Molecular and microscopic identification of sulphatereducing bacteria in multispecies biofilms. Appl Environ Microbiol 58:614-623

Ammerman JW, Fuhrman JA, Hagström $\AA$, Azam F (1984) Bacterioplankton growth in seawater: I. Growth kinetics and cellular characteristics in seawater cultures Mar Ecol Prog Ser 18:31-39

Amon RMW, Benner R (1994) Rapid cycling of highmolecular-weight dissolved organic matter in the ocean. Nature 369:549-551

Amy PS, Morita RY (1983) Starvation-survival patterns of sixteen freshly isolated open-ocean bacteria. Appl Environ Microbiol 45:1109-1115

Anderson JIW, Heffernan WP (1965) Isolation and characterization of filterable marine bacteria. J Bacteriol 90: $1713-1718$

Anderson IC, Rhodes MW, Kator HI (1983) Seasonal variation in survival of Escherichia coli exposed in situ in membrane diffusion chambers containing filtered and nonfiltered estuarine water. Appl Environ Microbiol 45:1877-1883

Andrews JH, Harris RF (1986) r- and K-selection and microbial ecology. Adv Microb Ecol 9:99-147

Austin B (1988) Methods in aquatic bacteriology. John Wiley \& Sons, Chichester

Azam F, Cho B (1987) Bacterial utilization of organic matter in the sea. In: Fletcher M, Gray TRG, Jones JG (eds) Ecology of microbial communities. Symp Soc Gen Microbiol 41: 261-281

Azam F, Fuhrman JA (1984) Measurement of bacterioplankton growth in the sea and its regulation by environmental conditions. In: Hobbie JE, Williams PJ (eds) Heterotrophic activity in the sea Plenum Publishing Corp, New York, p $179-196$

Azam F. Hodson RE (1977) Size distribution and activity of marine microheterotrophs. Limnol Oceanogr 22:492-501

Bada JL, Lee C (1977) Decomposition and alteration of organic compounds dissolved in seawater. Mar Chem 5: $523-534$

Baker RM, Singleton FL, Hood MA (1983) The effects of nutrient deprivation on Vibrio cholera. Appl Environ Microbiol 46:930-940

Barcina I, González JM, Iriberri J, Egea L (1989) Effect of visible light on progressive dormancy of Escherichia coli cells during the survival process in natural fresh water. Appl Environ Microbiol 55:246-251

Baross JA, Hanus FJ, Morita RY (1974) The effects of hydrostatic pressure on uracil uptake, ribonucleic acid synthesis, and growth of three obligately psychrophilic marine vibrios, Vibrio alginolyticus, and Escherichia coli. In: Colwell RR, Morita RY (eds) Effect of the ocean environment on microbial activities. University Park Press, Baltimore, p 180-202 
Baxter M. Sieburth JMCN (1984) Metabolic and ultrastructural response to glucose of two eurytrophic bacteria isolated from seawater at different enriching concentrations. Appl Environ Microbiol 47:31-38

Begon M. Harper JL, Townsend CR (1986) Ecology: ındividuals, population and communities. Blackwell Science Publ, Oxford

Bianchı A, Guiliano L (1996) Enumeration of viable bacterı in the marine pelagic environment. Appl Environ Microbiol 62: $174-177$

Billen G, Joirıs C, Meyer-Reil L, Lindeboom H (1990) Role of bacteria in the North Sea ecosystem. Neth J Sea Res 26: $265-293$

Bjornsen Pl (1986) Automatic determination of bacterıoplankton biomass by image analysis. Appl Environ Microbiol 51 $1199-1204$

Borsheim KY, Bratbak G, Heldal M (1990) Enumeration and biomass estimation of planktonic bacteria and viruses by transmission electron microscopy. Appl Environ Microbiol $56: 352-356$

Britschgi TB, Giovannoni S (1991) Phylogenetic analysis of a natural marine bacterioplankton population by rRNA gene cloning and sequencing. Appl Environ Microbiol 57: $1707-1713$

Buck JD (1974) Effects of medium composition on the recovery of bacteria from seawater. J Exp Mar Biol Ecol 15:25-34

Buck JD (1979) The plate count in aquatic microbiology. In: Costerton JW, Colwell RR (eds) Native aquatic bacteria: enumeration activity and ecology. American Society for Testing Materials, Philadelphia, p 19-28

Button DK (1985) Kinetics of nutrient-limited transport and microbial growth. Microbiol Rev 49:270-297

Button DK (1991) Biachemical basis for whole-cell uptake kinetics: specific affinity, oligotrophic capacity, and the meaning of the Michaelis constant. Appl Environ Microbiol 57:2033-2038

Button DK (1993) Nutrient-limited microbial growth kinetics: overview and recent advances. Ant Leeuwenhoek 63: $225-235$

Button DK, Robertson BR (1989) Kinetics of bacterial processes in natural aquatic systems based on biomass as determined by high-resolution flow cytometry. Cytometry 10:558-563

Button DK, Schut F, Quang P, Martin R, Robertson BR (1993) Viability and isolation of marine bacteria by dilution culture: theory, procedures and initial results. Appl Environ Microbiol 59: 881-891

Byrd JJ, Colwell RR (1990) Maintenance of plasmids pBR322 and pUC8 in nonculturable Escherichia coli in the marine environment. Appl Environ Microbiol 56:2104-2107

Calcott PH, Postgate JR (1972) On substrate accelerated death in Klebsiella aerogenes. J Gen Microbiol 70:115-122

Carlucci AF, Shimp SL (1974) Isolation and growth of a marine bacterium in low concentrations of substrate. In: Colwell RR, Morita RY (eds) Effect of the acean environment on microbial activities. University Park Press, Baltimore, p 363-367

Carlucci AF, Shimp SL, Craven DB (1986) Growth characteristics of low-nutrient bacteria from the north-east and central Pacific Ocean. FEMS Microbiol Ecol 38:1-10

Carlucci AF, Shimp SL, Craven DB (1987) Bacterial response to labile dissolved organic matter increases associated with marine discontinuities. FEMS Microbiol Ecol 45: $211-220$

Carlucci AF, Williams PM (1978) Stimulated in situ growth rates of pelagic marine bacteria. Naturwissenschaften 65 : $541-542$
Cho BC, Azam F (1988) Major role of bacteria in biogeochemical fluxes in the ocean's interior. Nature 332:441-443

Coffin RB (1989) Bacterial uptake of dissolved free and combined amino acids in estuarine waters. Limnol Oceanogr 34:531-542

Collins SH, Jarvis AW, Linsay RJ, Hamilton WA (1976) Proton movements coupled to lactate and alanine transport in Escherichla coli: isolation of mutants with altered stoichiometry in alanine transport. J Bacteriol 126: 1232-1244

Dawes EA (1976) Endogenous metabolism and the survival of starved prokaryotes. In: Gray TRG, Postgate JR (eds) The survival of vegetative microbes. Soc Gen Microbiol Symposium 26, Cambridge University Press, Cambridge, p $19-53$

Dawson MP, Humphrey BA, Marshall KC (1981) Adhesion: a tactic in the survival strategy of a marine vibrio during starvation. Curr Microbiol 6:195-199

Dawson R, Gocke K (1978) Heterotrophic activity in comparison to the free amino acid concentrations in Baltic sea water samples. Oceanol Acta 1:45-54

DeLong EF, Franks DG, Alldredge AL (1993) Phylogenetic diversity of aggregate-attached vs. free-living marine bacterial assemblages. Limnol Oceanogr 38:924-934

Dortch Q, Packard TT (1989) Differences in biomass structure between oligotrophic and eutrophic marine ecosystems. Deep Sea Res 36:223-240

Douglas DJ, Novitsky JA, Fournier RO (1987) Microautoradiography-based enumeration of bacteria with estimates of thymidine-specific growth and production rates. Mar Ecol Prog Ser 36:91-99

Eguchi Mi Ishida Y (1990) Oligotrophic properties of heterotrophic bacteria and in situ heterotrophic activity in pelagic seawaters. FEMS Microbiol Ecol 73:23-30

Eguchi M. Kawai A (1992) Distribution of oligotrophic and eutrophic bacteria in fish culturing inland bays. Nippon Suisan Gakkaishi 58:119-125

Equchi $M$, Nishikawa $T$, MacDonald $K$, Cavicchioli $R$, Gottschal JC, Kjelleberg S (1996) Responses to stress and nutrient availability by the marine ultramicrobacterium Sphingomonas sp. strain RB2256. Appl Environ Microbiol 62:1287-1294

Fein RL, MacLeod RA (1975) Characterization of neutral amino acid transport in a marine pseudomonad. $J$ Bacteriol 124: 1177-1190

Felter RA, Colwell RR, Chapman GB (1969) Morphology and round body formation in Vibrio marinus. J Bacteriol 99: 326-335

Ferguson RL, Buckley EN, Palumbo AV (1984) Response of marine bacterioplankton to differential filtration and confinement. Appl Environ Microbiol 47: 49-55

Ferguson RL, Rublee P (1976) Contribution of bacteria to standing crop of coastal plankton. Limnol Oceanogr 21 $141-145$

Fletcher M (1984) Comparative physiology of attached and free-living bacteria. In: Marshall KC (ed) Microbial adhesion and aggregation. Dahlem Konferenzen. SpringerVerlag, Berlin, p 223-232

Fry JC (1990) Oligotrophs. In: Edwards C (ed) Microbiology of extreme environments. Open University Press, Milton Keynes, p 93-116

Fuhrman JA (1981) Influence of method on the apparent size distribution of bacterioplankton cells: epifluorescence microscopy compared to scanning electron microscopy Mar Ecol Prog Ser 5:103-106

Fuhrman JA Azam F (1980) Bacterioplankton secondary production estimates for coastal waters of British Columbia, 
Antarctica, and California. Appl Environ Microbiol 39 1085-1095

Fuhrman JA, Azam F (1982) Thymidine incorporation as a measure of heterotrophic bacterioplankton production in marine surface waters: evaluation and field results. Mar Biol 66:109-120

Fuhrman JA, Ferguson RL (1986) Nanomolar concentrations and rapid turnover of dissolved free amino acids in seawater: agreement between chemical and microbiological measurements. Mar Ecol Prog Ser 33:237-242

Fuhrman JA, Lee SH, Masuchi Y, Davis AA, Wilcox RM (1994) Characterization of marine prokaryortic communities via DNA and RNA. Microb Ecol 28:133-145

Fuhrman JA, McCallum K, Davis A (1993) Phylogenetic diversity of subsurface marine microbial communities from the Atlantic and Pacific Oceans. Appl Environ Microbiol 59:1294-1302

Fuhrman JA, Sleeter TD, Carlson CA, Proctor LM (1989) Dominance of bacterial biomass in the Sargasso Sea and its ecological implications. Mar Ecol Prog Ser 57:207-217

Fukam, K, Simidu U, Taga N (1983) Distribution of heterotrophic bacteria in relation to the concentration of particulate organic matter in seawater. Can J Microbiol 29:570-575

Furlong CE (1987) Osmotic-shock-sensitive transport systems. In: Neidhardt FC (ed) Escherichia coli and Salmonella typhimurium: cellular and molecular biology. American Society for Microbiology, Washington, DC, p 768-796

Geesey GG, Morita RY (1979) Capture of arginine at low concentrations by a marine psychrophilic bacterium. Appl Environ Microbiol 38:1092-1097

Giovannoni SJ, Britschgi TB, Moyer CL, Field KG (1990) Genetic diversity in Sargasso Sea bacterioplankton. Nature 345:60-63

Giovannoni SJ, DeLong EF, Olsen GJ, Pace NR (1988) Phylogenetic group-specific oligonucleotide probes for identification of single microbial cells. J Bacteriol 170:720-726

Goldman JC, Caron DA, Dennet MR (1987) Regulation of gross growth efficiency and ammonium regeneration in bacteria by substrate C:N ratio. Limnol Oceanogr 32: $1239-1252$

Gonzalez JM, Sherr EB, Sherr BF (1990) Size-selective grazing on bacteria by natural assemblages of estuarine flagellates and ciliates. Appl Environ Microbiol 56:583-589

Gotschalk C, Alldredge AL (1989) Enhanced primary production and nutrient regeneration within aggregated marine diatoms: implications for mass flocculation of diatom blooms. Mar Biol 103:119-130

Gottschal JC (1990) Phenotypic response to environmental changes. FEMS Microbiol Ecol 74:93-102

Gottschal JC. Dijkhuizen L (1988) The place of the continuous culture in ecological research. In: Wimpenny JWT (ed) Handbook of laboratory model systems for microbial ecosystems, Vol 1. CRC Press, Boca Raton, FL, p 19-79

Gottschal JC, Harder W, Prins RA (1992) Principles of enrichment, isolation, cultivation and preservation of bacteria. In: Balows A, Trüper HG, Dworkin M, Harder W, Schleifer $\mathrm{KH}$ (eds) The Prokaryotes, Vol I, 2nd edn. SpringerVerlag, Berlin, p 149-196

Hagström \&, Ammerman JW, Henrichs S, Azam F (1984) Bacterioplankton growth in seawater: II. Organic matter utilization during steady-state growth in seawater cultures Mar Ecol Prog Ser 18:41-48

Hagstrom $\AA$, Azam $F$, Andersson A, Wikner J, Rassoulzadegan $F(1988$ ) Microbial loop in an oligotrophic pelagic marine ecosystem: possible roles of cyanobacteria and nanoflagellates in the organic fluxes. Mar Ecol Prog Ser 49:171-178
Hahn D, Amann RI, Ludwig W, Akkermans ADL, Schleifer $\mathrm{KH}$ (1992) Detection of micro-organisms in soil after in situ hybridization with rRNA-targeted, fluorescently labelled oligonucleotides. J Gen Microbiol 138.879-887

Hall BG, Yokoyama S, Calhoun DH (1984) Role of cryptic genes in microbial evolution. Mol Biol Evol 1:109-124

Hamilton RD. Carlucci AF (1966) Use of ultraviolet-irradiated seawater in the preparation of culture media. Nature 211: $483-484$

Hamilton RD, Morgan KM, Strickland JDH (1966) The glucose uptake kinetics of some marine bacteria. Can J Microbiol 21:995-1003

Harder W, Dijkhuizen L (1982) Strategies of mixed substrate utilization in microorganisms. Philos Trans R Soc Lond Biol Sci 297:459-480

Harder W, Dijkhuizen L (1983) Physiological responses to nutrient limitation. Annu Rev Microbiol 37:1-23

Harder W, Dijkhuizen L, Veldkamp H (1984) Environmental regulation of microbial metabolism. In: Kelly DP, Carr NG (eds) The Microbe 1984: Part II prokaryotes and eukaryotes. Society for General Microbiology Symposium 36, Cambridge University Press, Cambridge, p 51-95

Harvey GR (1983) Dissolved carbohydrates in the New York bight and the variability of marine organic matter. Mar Chem 12:333-339

Heldal M, Bratbak G (1991) Production and decay of viruses in aquatic environments. Mar Ecol Prog Ser 72:205-212

Hensiek R, Krupp G, Stackebrandt E (1992) Development of diagnostic oligonucleotide probes for four Lactobacillus species occurring in the intestinal tract. Syst Appl Microbiol 15:123-128

Hicks RE, Amann RI, Stahl DA (1992) Dual staining of natural bacterioplankton with 4',6-diamidino-2-phenylindole and fluorescent oligonucleotide probes targeting kingdomlevel 16S rRNA sequences. Appl Environ Microbiol 58: $2158-2163$

Higgins CF, Hyde SC, Mimmack MM, Gileadi U, Gill DR, Gallagher MP (1990) Binding protein-dependent transport systems. J Bioenerg Biomembr 22:571-592

Hirsch P, Bernhard M, Cohen SS, Ensign JC, Jannasch HW, Koch AL, Marshall KC, Matin A, Poindexter JS, Rittenberg SC, Schmidt DC, Veldkamp H (1979) Life under conditions of low nutrient concentrations. In: Shilo M (ed) Strategies of microbial life in extreme environments. Dahlem Konferenzen 1979, Springer-Verlag, Berlin, p 357-372

Hobbie JE, Daley RJ, Jasper S (1977) Use of Nucleopore filters for counting bacteria by fluorescence microscopy. Appl Environ Microbiol 33:1225-1228

Hodson RE, Azam F (1979) Occurrence and characterization of a phosphoenolpyruvate: glucose phosphotransferase system in a marine bacterium Serratia marinorubra. Appl Environ Microbiol 38:1086-1091

Hodson RE, Maccubbin AE, Pomeroy LR (1981) Dissolved adenosine triphosphate utilization by free-living and attached bacterioplankton. Mar Biol 64:43-51

Höfle MG (1983) Long-term changes in chemostat cultures of Cytophaga jonsonae. Appl Environ Microbiol 46 $1045-1053$

Höfle MG (1984) Transient responses of glucose-limited cultures of Cytophaga johnsonae to nutrient excess and starvation. Appl Environ Microbiol 47:356-362

Hollibaugh JT, Azam F (1983) Microbial degradation of dissolved proteins in seawater. Limnol Oceanogr 28 $1104-1116$

Hood MA, MacDonell MT (1987) Distribution of ultramicrobacteria in a Gulf Coast estuary and induction of ultramicrobacteria. Microb Ecol 14:113-127 
Hoppe HG (1983) Significance of exoenzymatic activities in the ecology of brackish water: measurements by means of methylumbelliferyl-substrate. Mar Ecol Prog Ser 11 299-308

Hoppe HG (1984) Attachment of bacteria: advantages and disadvantages for survival in the aquatic environment. In: Marshall KC (ed) Microbial adhesion and aggregation. Dahlem Konferenzen. Springer-Verlag, Berlin, p 283-301

Horowitz A, Krichevsky MI, Atlas RM (1983) Characteristics and diversity of subarctic marine oligotrophic, stenoheterotrophic, and euryheterotrophic bacterial populations. Can J Microbiol 29:527-535

Ingraham JL, Maaloe O. Neidhardt FT (1983) Growth of the bacterial cell. Sinauer Associates, Inc, Sunderland, MA

Iriberri J, Unanue M, Ayo B, Barcina l, Egea L (1990) Bacterial production and growth rate estimation from $\left[{ }^{3} \mathrm{H}\right]$ thymidine incorporation for attached and free-living bacteria in aquatic systems. Appl Environ Microbiol 56:483-487

Ishida Y, Eguchi M, Kadota H (1986) Existence of obligately oligotrophic bacteria as a dominant population in the south China Sea and the west Pacific Ocean. Mar Ecol Prog Ser 30:197-203

Ishida Y, Fukami K, Eguchi M, Yoshinaga I (1989) Strategies for growth of oligotrophic bacteria in the pelagic environment. In: Hattori $T$, Ishida Y, Maruyama Y, Morita RY, Uchida A (eds) Recent advances in microbial ecology. Jap Scien Soc Press, Tokyo, p 89-93

Ishida Y, Imai I, Miyagaki T, Kadota H (1982) Growth and uptake kinetics of a facultatively oligotrophic bacterium at low nutrient concentrations. Microb Ecol 8:23-32

Ishida Y, Kadota $H$ (1981) Growth patterns and substrate requirements of naturally occurring obligate oligotrophs. Microb Ecol 7:123-130

Jannasch HW (1967) Growth of marine bacteria at limiting concentrations of organic carbon in seawater. Limnol Oceanogr 12:264-271

Jannasch HW, Egli T (1993) Microbial growth kinetics: a historical perspective. Ant Leeuwenhoek 36:213-224

Jannasch HW, Jones GE (1959) Bacterial populations in seawater as determined by different methods of enumeration. Limnol Oceanogr 4:128-139

Jeffrey WH, Paul JH (1986) Activity measurements of planktonic microbial and microfouling communities in a eutrophic estuary. Appl Environ Microbiol 51:157-162

Jorgensen NOG, Sondergaard M (1984) Are dissolved amino acids free? Microb Ecol 10:301-316

Kaprelyants AS, Gottschal JC, Kell DB (1993) Dormancy in nonsporulating bacteria. FEMS Microbiol Rev 104:271-286

Kaprelyants AS, Kell DB (1993) Dormancy in stationary-phase cultures of Micrococcus luteus: flow-cytometric analysis of starvation and resuscitation. Appl Environ Microbiol 59:3187-3196

Karl DM (1979) Measurement of microbial activity and growth in the ocean by rates of stable ribonucleic acid synthesis. Appl Environ Microbiol 38: 850-860

Kasahara Y, Hattori T (1991) Analysis of bacterial populations in a grassland soil according to rates of development on solid media. FEMS Microbiol Ecol 86:95-102

Kay WW, Gronlund AF (1969) Influence of carbon or nitrogen starvation on amino acid transport in Pseudomonas aeruginosa. J Bacteriol 100:276-282

Keil RG, Kirchman DL (1991) Contribution of dissolved free amino acids and ammonium to the nitrogen requirements of heterotrophic bacterioplankton. Mar Ecol Prog Ser 73:1-10

Kemp PF, Lee S, LaRoche J (1993) Estimating the growth rate of slowly growing marine bacteria from RNA content. Appl Environ Microbiol 59: 2594-2601
Kerkhof L, Ward BB (1993) Comparison of nucleic acid hybridization and fluorometry for measurement of the relationship between RNA/DNA ratio and growth rate in a marine bacterium. Appl Environ Microbiol 59: 1303-1309

Kirchman DL (1990) Limitation of bacterial growth by dissolved organic matter in the subarctic Pacific. Mar Ecol Prog Ser 62:47-54

Kirchman DL, Keil RG, Wheeler PA. (1989) The effect of amino acids on ammonium utilization and regeneration by heterotrophic bacteria in the subarctic Pacific. Deep Sea Res 36:1763-1776

Kirchman D, Mitchell R (1982) Contribution of particle-bound bacteria to the total microheterotrophic activity in five ponds and two marshes. Appl Environ Microbiol 43: 200-209

Kirchman D, Murray RE, Hodson RE (1986) Rates of DNA and protein synthesis by heterotrophic bacteria in aquatic environment: a comparison between the thymidine and leucine approaches. In: Megysar F, Ganter M (eds) Perspectives in microbial ecology. Slovene Society for Microbiology, Ljubljana, p 631-637

Kjelleberg S (1984) Effects of interfaces on survival mechanisms of copiotrophic bacteria in low-nutrient habitats. In: Klug MJ, Reddy CA (eds) Current perspectives in microbial ecology. American Society for Microbiology, Washington, DC, p 151-159

Kjelleberg $\mathrm{S}$, Hermansson M. Mårdén P, Jones GW (1987) The transient phase between growth and nongrowth of heterotrophic bacteria, with emphasis on the marine environment. Annu Rev Microbiol 41:25-49

Kjelieberg S, Humphrey BA, Marshall KC (1982) Effect of interfaces on small, starved marine bacteria. Appl Environ Microbiol 43:1166-1172

Kjelleberg S, Humphrey BA, Marshall KC (1983) Initial phases of starvation and activity of bacteria at surfaces. Appl Environ Microbiol 46:978-984

Kjelleberg S, Marshall KC, Hermansson M (1985) Oligotrophic and copiotrophic marine bacteria - observations related to attachment. FEMS Microbiol Ecol 31:89-96

Kogure K, Simidu U, Taga N (1979) A tentative direct microscopic method for counting living marine bacteria. Can J Microbiol 25:415-420

Kogure K, Simidu U, Taga N (1980) Distribution of viable marine bacteria in neritic seawater around Japan. Can J Microbiol 26:318-323

Konings WN, Poolman B, Driessen AJM (1989) Bioenergetics and solute transport in lactococci. CRC Crit Rev 16: $419-476$

Konings WN, Veldkamp H (1983) Energy transduction and solute transport mechanisms in relation to environments occupied by microorganisms. In: Slater JH, Wittenbury $R$, Wimpenny JWT (eds) Microbes in their natural environments. The Society for General Microbiology Symposium 34, Cambridge University Press, Cambridge, p $153-186$

Kurath G, Morita RY (1983) Starvation-survival physiological studies of a marine $P_{\text {seudomonas }} \mathrm{p}$. Appl Environ Microbiol 45:1206-1211

Kuznetsov SI, Dubinia GA, Lapteva NA (1979) Biology of oligotrophic bacteria. Annu Rev Microbiol 33:377-387

Larsson U, Hagström \& (1982) Fractionated phytoplankton primary production, exudate release and bacterial production in a Baltic eutrophication gradient. Mar Biol 67 : $57-70$

Law AT, Button DK (1977) Multiple-carbon-source-limited growth kinetics of a marine coryneform bacterium. $J$ Bacteriol 129:115-123 
Lee S, Fuhrman JA (1987) Relationships between biovolume and biomass of naturally derived marine bacterioplankton. Appl Environ Microbiol 53:1298-1303

Li WH (1984) Retention of cryptic genes in microbial populations. Mol Biol Evol 1:212-218

Li WKW, Dickie PM (1985) Growth of bacteria in seawater filtered through $0.2 \mu \mathrm{m}$ Nucleopore membranes: implications for dilution experiments. Mar Ecol Prog Ser 26 $245-252$

Liesack W, Stackebrandt E (1992) Unculturable microbes detected by molecular sequences and probes. Biodiversity Conserv 1:250-262

Linley EAS, Newell RC, Lucas MI (1983) Quantitative relationships between phytoplankton, bacteria and heterotrophic microflagellates in shelf waters. Mar Ecol Prog Ser $12: 77-89$

MacDonell MT, Hood MA (1982) Isolation and characterization of ultramicrobacteria from a Gulf Coast estuary. Appl Environ Microbiol 43:566-571

MacLeod RA (1985) Marine microbiology far from the sea. Annu Rev Microbiol 39:1-20

Mallory LM, Austin B, Colwell RR (1977) Numerical taxonomy and ecology of oligotrophic bacteria isolated from the estuarine environments. Can J Microbiol 23:733-750

Mảrdén P, Nyström T, Kjelieberg S (1987) Uptake of leucine by a Gram-negative heterotrophic bacterium during exposure to starvation conditions. FEMS Microbiol Ecol 45: 233-241

Mårdén $\mathrm{P}$, Tunlid A, Malmcrona-Friberg K, Odham G, Kjelleberg $S$ (1985) Physiological and morphological changes during short term starvation of marine bacterial isolates. Arch Microbiol 142:326-332

Martin P. MacLeod RA (1984) Observations on the distinction between oligotrophic and eutrophic marine bacteria. Appl Environ Microbiol 47:1017-1022

Martinez J. Azam F (1993) Periplasmic aminopeptidase and alkaline phosphatase activities in a marine bacterium: implications for substrate processing in the sea. Mar Ecol Prog Ser 92:89-97

Matin A, Auger EA, Blum PH, Schultz JE (1989) Genetic basis for starvation survival in nondifferentiating bacteria. Annu Rev Microbiol 43:293-316

McCambridge J, McMeekin TA (1981) Effect of solar radiation and predacious organisms on survival of fecal and other bacteria. Appl Environ Microbiol 41:1083-1087

McManus GB, Peterson WT (1988) Bacterioplankton production in the nearshore zone during upwelling off central Chile. Mar Ecol Prog Ser 43:11-17

Menzel DW (1964) The distribution of dissolved organic carbon in the Western Indian Ocean. Deep Sea Res 11 . $757-765$

Meyer-Reil LA (1978) Autoradiography and epifluorescence microscopy combined for the determination of number and spectrum of actively metabolizing bacteria. Appl Environ Microbiol 36:506-512

Moaledj K (1978) Qualitative analysis of an oligocarbophilic aquatic microflora in the Plußsee. Arch Hydrobiol 82:98-113

Monod J (1950) La technique de culture continue. Théorie et applications. Ann Inst Pasteur Paris 79:390-410

Mopper K, Lindroth P (1982) Diel and depth variations in dissolved free amino acids and ammonium in the Baltic Sea determined by shipboard HPLC analysis. Limnol Oceanogr 27:336-347

Morita RY (1982) Starvation survival of heterotrophs in the marine environment. Adv Microb Ecol 6:171-198

Morita RY (1985) Starvation and miniaturisation of heterotrophs, with special emphasis on maintenance of the starved viable state. In: Fletcher M. Floodgate GD (eds) Bacteria in their natural environment. Academic Press, Now York, p 111-131

Morita RY (1988) Bioavailability of energy and its relation to growth and starvation survival in nature. Can J Microbiol 34:436-441

Moyer CL, Morita RY (1989) Effect of growth rate and starvation-survival on the viability and stability of a psychrophilic marine bacterium. Appl Environ Microbiol 55:1122-1127

Mullins TD, Britschgi TB, Krest RL, Giovannoni SJ (1994) Genetic comparisons reveal the same unknown bacterial lineages in Atlantic and Pacific bacterioplankton communities Limnol Oceanogr 40:148-158

Münster U (1985) Investigations about structure, distribution and dynamics of different organic substrates in the DOM of lake Plußsee. Arch Hydrobiol Suppl 70:429-480

Münster U (1993) Concentrations and fluxes of organic carbon substrates in the aquatic environment. Ant Leeuwenhoek 63:243-274

Nagata T (1987) Production rate of planktonic bacteria in the north basin of Lake Biwa, Japan. Appl Environ Microbiol 53:2872-2882

Nagata T, Watanabe Y (1990) Carbon- and nitrogen-to-volume ratios of bacterioplankton grown under different nutritional conditions. Appl Environ Microbiol 56:1303-1309

Nilsson L, Oliver JD, Kjelleberg S (1991) Resuscitation of Vibrio vulnificus from the viable but non culturable state J Bacteriol 173:5054-5059

Nissen $H$ (1987) Long term starvation of a marine bacterium, Alteromonas denitrificans, isolated from a Norwegian fjord. FEMS Microbiol Ecol 45:173-183

Nissen H, Nissen P, Azam F (1984) Multiphasic uptake of Dglucose by an oligotrophic marine bacterium. Mar Ecol Prog Ser 16:155-160

Novitsky JA, Morita RY (1976) Morphological characterization of small cells resulting from nutrient starvation of a psychrophilic marine vibrio. Appl Environ Microbiol 32 $617-622$

Novitsky JA, Morita RY (1977) Survival of a psychrophilic marine vibrio under long-term nutrient starvation. Appl Environ Microbiol 33:635-641

Novitsky JA, Morita RY (1978) Starvation induced barotolerance as a survival mechanism of a psychrophilic marine vibrio in the waters of the Antarctic Convergence. Mar Biol 49:7-10

Nyström T, Mărdén P, Kjelleberg S (1986) Relative changes in incorporation rates of leucine and methionine during starvation survival of two bacteria isolated from marine waters. FEMS Microbiol Ecol 38:285-292

Ohta H, Taniguchi S (1988) Respiratory characteristics of two oligotrophic bacteria: Agromonas oligotrophica JCM 1494 and Aeromonas hydrophila 315. J Gen Appl Microbiol 34: $355-365$

Oliver JD (1993) Formation of viable but nonculturable cells. In: Kjelleberg S (ed) Starvation in bacteria. Plenum Press, New York, p 239-272

Oliver JD, Nilsson L, Kjelleberg $S$ (1991) Formation of nonculturable Vibrio vulnificus cells and its relationship to the starvation state. Appl Environ Microbiol 57:2640-2644

Oppenheimer $\mathrm{CH}$ (1952) The membrane filter in marine microbiology. J Bacteriol 64:783-786

Poindexter JS (1981) Oligotrophy. Fast and famine existence. Adv Microb Ecol 5:63-89

Poindexter JS, Leadbetter ER (1986) Bacteria in nature, Vol 2, Methods and special applications in bacterial ecology. Plenum Press, New York 
Poolman B, Smid EJ, Veldkamp H, Konings WN (1987) Bioenergetic consequences of lactose starvation for continuous cultured Streptococcus cremoris. J Bacteriol 169: $1460-1468$

Postgate JR (1976) Death in macrobes and microbes. In: Gray TRG, Postgate JR (ed) The survival of vegetative microbes. Cambridge University Press, Cambridge, p 1-19

Poulet SA, Martin-Jézéquel V, Head RN (1984) Distribution of dissolved free amino acids in the Ushant front region. Mar Ecol Prog Ser 18:49-55

Pratt D, Reynolds J (1974) Selective media for characterizing marine bacterial populations. In: Colwell RR, Morita RY (ed) Effect of the ocean environment on microbial activities. University Park Press, Baltimore, p 258-267

Preyer JM, Oliver JD (1993) Starvation-induced thermal tolerance as a survival mechanism in a psychrophilic marine bacterium. Appl Environ Microbiol 59:2653-2656

Ramsing NB, Fossing H, Ferdelman TG, Andersen F, Thamdrup B (1996) Distribution of bacterial populations in a stratified fjord (Mariager Fjord, Denmark) quantified by in situ hybridization and related to chemical gradients in the water column. Appl Environ Microbiol 62:1391-1404

Rehnstam AS, Bäckman S, Smith DC, Azam F, Hagström $\AA$ (1993) Blooms of sequence-specific culturable bacteria in the sea. FEMS Microbiol Ecol 102:161-166

Reichardt W, Morita RY (1982) Survival stages of a psychrotrophic Cytophaga jonsonae strain. Can J Microbiol 28: $841-850$

Riley GA (1963) Organic aggregates in sea water and the dynamics of their formation and utilization. Limnol Oceanogr 8:372-381

Rodriguez GG, Phipps D, Ishiguro K, Ridgway HF (1992) Use of a fluorescent redox probe for direct visualization of actively respiring bacteria. Appl Environ Microbiol 58: $1801-1808$

Rollins DM, Colwell RR (1986) Viable but nonculturable stage of Campylobacter jejuni and its role in survival in the natural aquatic environment. Appl Environ Microbiol 52: $531-538$

Roszak DB, Colwell RR (1987) Survival strategies of bacteria in the natural environment. Microbiol Rev 51:365-379

Roszak DB, Grimes DJ, Colwell RR (1984) Viable but nonrecoverable stage of Salmonella enteritidis in aquatic systems. Can J Microbiol 30:334-338

Schmidt TM, DeLong EF, Pace NR (1991) Analysis of a marine picoplankton community by $16 \mathrm{~S}$ rRNA gene cloning and sequencing. J Bacteriol 173:4371-4378

Schut F (1994) Ecophysiology of a marine ultramicrobacterium. PhD thesis, University of Groningen

Schut F, de Vries EJ, Gottschal JC, Robertson BR, Harder W, Prins RA, Button DK (1993) Isolation of typical marine bacteria by dilution culture: growth, maintenance, and characteristics of isolates under laboratory conditions. Appl Environ Microbiol 59:2150-2160

Schut F, Jansen M, Pedro Gomes TM, Gottschal JC, Harder W, Prins RA (1995) Substrate uptake and utilization by a marine ultramicrobacterium. Microbiology 141:351-361

Semenov AM (1991) Physiological bases of oligotrophy of microorganisms and the concept of microbial community. Microb Ecol 22: 239-247

Shirey JJ, Bissonnette GK (1991) Detection and identification of groundwater bacteria capable of escaping entrapment on $0.45 \mu \mathrm{m}$-pore-size membrane filters. Appl Environ Microbiol 57:2251-2254

Sieburth J McN, Johnson KM, Burney C, Lavoie DM (1977) Estimation of in situ rates of heterotrophy using diurnal changes in dissolved organic matter and growth rates of picoplankton in diffusion culture. Helgol Wiss Meeresunters 30:565-574

Simidu U (1974) Improvement of media for enumeration and isolation of heterotrophic bacteria in seawater. In: Colwell RR, Morita RY (eds) Effect of the ocean environment on microbial activities. University Park Press, Baltimore, p 249-25?

Simon M (1987) Biomass and production of small and large free-living and attached bacteria in Lake Constance. Limnol Oceanogr 32:591-607

Simon M, Azam F (1989) Protein content and protein synthesis rates of planktonic marine bacteria. Mar Ecol Prog Ser 51:201-213

Smith DC, Simon M, Alldredge AL, Azam F (1992) lntense hydrolytic enzyme activity on marine aggregates and implications for rapid particle dissolution. Nature 359:139-142

Sommville $M$ (1984) Measurement and study of substrate specificity of exoglucosidase activity in eutrophic water. Appl Environ Microbiol 48:1181-1185

Sommville $M$, Billen $G$ (1983) A method for determining exoproteolytic activity in natural waters. Limnol Oceanogr 28:190-193

Stackebrandt E (1985) Phylogeny and phylogenetic classification of prokaryotes. In: Schleifer KH, Stackebrandt E (eds) Evolution of prokaryotes. Academic Press Inc, London, p 309-334

Stackebrandt E, Rainey FA (1995) Partial and complete $16 \mathrm{~S}$ rDNA sequences, their use in generation of $16 \mathrm{~S}$ rDNA phylogenetic trees and their implications in molecular ecological studies. In: Akkermans ADL, van Elsas JD, de Bruijn FJ (eds) Molecular microbial ecology manual. Part 3.1.1. Kluwer Academic Publ, Dordrecht p 1-17

Stahl DA, Flesher B, Mansfield HR, Montgomery L (1988) Use of phylogenetically based hybridization probes for studies of ruminal microbial ecology. Appl Environ Microbiol $54: 1079-1084$

Stevenson LH (1978) A case for bacterial dormancy in aquatic systems. Microb Ecol 4:127-133

Stouthamer AH, Kooijman SALM (1993) Why it pays for bacteria to delete disused DNA and to maintain megaplasmids. Ant Leeuwenhoek 63:39-43

Suzuki N, Kato K (1953) Studies of suspended materials Marine snow in the sea. I. Sources of marine snow. Bull Fac Fish Hokkaido Univ 4:132-135

Tabor PS, Neihof RA (1982) Improved microautoradiographic method to determine individual microorganisms active in substrate uptake in natural waters. Appl Environ Microbiol 44:945-953

Tabor PS, Neihof RA (1984) Direct determination of activities for microorganisms of Chesapeake Bay populations. Appl Environ Microbiol 48:1012-1019

Tabor PS, Ohwada K, Colwell RR (1981) Filterable marine bacteria found in the deep sea: distribution, taxonomy, and response to starvation. Microb Ecol 7:67-83

Tada Y, Ihmori M, Yamaguchi J (1995) Oligotrophic bacteria isolated from clinical materials. J Clin Microbiol 33: 493-494

Torrella F, Morita RY (1981) Microcultural study of bacterial size changes and microcolony and ultramicrocolony formation by heterotrophic bacteria in seawater. Appl Environ Microbiol 41:518-527

Upton AC, Nedwell DB (1989) Nutritional flexibility of oligotrophic and copiotrophic Antarctic bacteria with respect to organic substrates FEMS Microbiol Ecol 62:1-6

Vaccaro RF, Hicks SE, Jannasch HW, Carey FG (1968) The occurrence and role of glucose in seawater. Limnol Oceanogr 13:356-360 
Van der Kooij D, Oranje JP, Hijnen WAM (1982) Growth of Pseudomonas aeruginosa in tap water in relation to utilization of substrates at concentrations of a few micrograms per liter Appl Environ Microbiol 44:1086-1095

Van der Kooij D, Visser A, Hijnen WAM (1980) Growth of Aeromonas hydrophila at low concentrations of substrates added to tap water. Appl Environ Microbiol 39 : 1198-1204

Van Es FB, Meyer-Reil LA (1982) Biomass and metabolic activity of heterotrophic marine bacteria. In: Marshall $\mathrm{KC}$ (ed) Adv Microb Ecol 6:111-170

Van Gemerden H, Kuenen GJ (1984) Strategies for growth and evolution of microorganisms in oligotrophic habitats. In: Hobbie JEleB, Williams PJ (eds) Heterotrophic activity in the sea. Plenum Press, New York, p 25-44

Veldkamp $H$, van Gemerden $H$, Harder W, Laanbroek HJ (1984) Competition among bacteria: an overview. Adv Microb Ecol 6:279-290

Vives Rego J, Billen G, Fontiqny A, Sommville M (1985) Free and attached proteolytic activity in water environments Mar Ecol Prog Ser 21:245-249

Wagner M, Amann R, Lemmer H, Schleifer KH (1993) Probing activated sludge with oligonucleotides specific for proteobacteria: inadequacy of culture-dependent methods for describing microbial community structure. Appl Environ Microbiol 59:1520-1525

Wangersky PJ (1977) The role of particulate matter in the productivity of surface waters. Helgol Wiss Meeresunters 30:546-564

Ward DM, Weller R, Bateson MM (1990) 16S rRNA sequences reveal numerous uncultured microorganisms in a natural community. Nature 345:63-65

Watson SW, Novitsky TJ, Quinby HL, Valois FW (1977) Determination of bacterial number and biomass in the marine environment. Appl Environ Microbiol 33: 940-946

Wiebe WJ, Pomeroy LR (1972) Microorganisms and their association with aggregates and detritus in the sea: a

Responsible Subject Editor: T. Fenchel, Helsinger, Denmark microscopic study. Mem Ist Ital Idrobiol (Suppl) 29: 325-352

Williams PJ leB (1970) Heterotrophic utilization of dissolved organic compounds in the sea 1 . Size distribution of population and relationship between respiration and incorporation of growth substances. $\mathrm{J}$ Mar Biol Assoc UK $50: 859-870$

Winogradsky S (1949) Microbiologie du sol. Problèmes et méthodes. Masson \& Cie, Paris

Witzel KP, Moaledj K, Overbeck HJ (1982) A numerical taxonomic comparison of oligocarbophilic and saprophytic bacteria isolated from Lake Plußsee. Arch Hydrobiol 95: $507-520$

Wright RT (1978) Measurement and significance of specific activity in the heterotrophic bacteria of natural waters. Appl Environ Microbiol 36:297-305

Xu HS, Roberts N, Singleton FL, Attwell RW, Grimes DJ, Colwell RR (1982) Survival and viability of non-culturable Escherichia coli and Vibrio cholerae in the estuarine and marine environment. Microb Ecol 8:313-323

Yanagita T, Ichikawa T, Tsuji T, Kamata Y, Ito K, Sasaki M (1978) Two trophic groups of bacteria, oligotrophs and eutrophs: their distribution in fresh and sea water areas in the central northern Japan. J Gen Appl Microbiol 24 : $59-88$

Yoshinaga I, Fukami K, Ishida Y (1991) Comparison of DNA and protein synthesis rates of bacterial assemblages between coral reef waters and pelagic waters in tropical ocean. Mar Ecol Prog Ser 76:167-174

Zimmerman R, Iturriaga R, Becker-Birck J (1978) Simultaneous determination of the total number of aquatic bacteria and the number thereof involved in respiration. Appl Environ Microbiol 36:926-935

ZoBell CE (1941) Studies on marine bacteria. I. The cultural requirements of heterotrophic aerobes. J Mar Res 4; $42-75$

ZoBell CE, Grant CW (1943) Bacterial utilization of low concentrations of organic matter. J Bacteriol 45:555-564

Manuscript first received: August 26, 1996

Revised version accepted: February 13, 1997 